\title{
Article \\ An Experimental Investigation on the Effect of Ferrous Ferric Oxide Nano-Additive and Chicken Fat Methyl Ester on Performance and Emission Characteristics of Compression Ignition Engine
}

\author{
Ameer Suhel ${ }^{1}$, Norwazan Abdul Rahim ${ }^{1, * \mathbb{D}}$, Mohd Rosdzimin Abdul Rahman ${ }^{1}$, Khairol Amali Bin Ahmad ${ }^{1} \mathbb{D}$, \\ Yew Heng Teoh ${ }^{2, *(\mathbb{D})}$ and Noh Zainal Abidin ${ }^{1}$ \\ 1 Faculty of Engineering, Universiti Pertahanan Nasional Malaysia, Kem, Sungai Besi 57000, Kuala Lumpur, \\ Malaysia; ameersuhelme@gmail.com (A.S.); rosdzimin@upnm.edu.my (M.R.A.R.); \\ khairol@upnm.edu.my (K.A.B.A.); noh@upnm.edu.my (N.Z.A.) \\ 2 School of Mechanical Engineering, Engineering Campus, Universiti Sains Malaysia, Nibong Tebal 14300, \\ Penang, Malaysia \\ * Correspondence: norwazan@upnm.edu.my (N.A.R.); yewhengteoh@usm.my (Y.H.T.)
}

Citation: Suhel, A.; Abdul Rahim, N.; Abdul Rahman, M.R.; Bin Ahmad, K.A.; Teoh, Y.H.; Zainal Abidin, N. An Experimental Investigation on the Effect of Ferrous Ferric Oxide Nano-Additive and Chicken Fat Methyl Ester on Performance and Emission Characteristics of Compression Ignition Engine. Symmetry 2021, 13, 265. https:// doi.org/10.3390/sym13020265

Received: 29 December 2020

Accepted: 27 January 2021

Published: 4 February 2021

Publisher's Note: MDPI stays neutral with regard to jurisdictional claims in published maps and institutional affiliations.

Copyright: (c) 2021 by the authors. Licensee MDPI, Basel, Switzerland. This article is an open access article distributed under the terms and conditions of the Creative Commons Attribution (CC BY) license (https:/ / creativecommons.org/licenses/by/ $4.0 /)$.

\begin{abstract}
In recent years, industries have been investing to develop a potential alternative fuel to substitute the depleting fossil fuels which emit noxious emissions. Present work investigated the effect of ferrous ferric oxide nano-additive on performance and emission parameters of compression ignition engine fuelled with chicken fat methyl ester blends. The nano-additive was included with various methyl ester blends at different ppm of 50,100, and 150 through the ultrasonication process. Probe sonicator was utilized for nano-fuel preparation to inhibit the formation of agglomeration of nanoparticles in base fuel. Experimental results revealed that the addition of 100 ppm dosage of ferrous ferric oxide nanoparticles in blends significantly improves the combustion performance and substantially decrease the pernicious emissions of the engine. It is also found from an experimental results analysis that brake thermal efficiency (BTE) improved by $4.84 \%$, a reduction in brake specific fuel consumption (BSFC) by $10.44 \%$, brake specific energy consumption (BSEC) by $9.44 \%$, exhaust gas temperature (EGT) by $19.47 \%$, carbon monoxides (CO) by $53.22 \%$, unburned hydrocarbon (UHC) by $21.73 \%$, nitrogen oxides (NOx) by $15.39 \%$, and smoke by $14.73 \%$ for the nano-fuel B20FFO100 blend. By seeing of analysis, it is concluded that the doping of ferrous ferric oxide nano-additive in chicken fat methyl ester blends shows an overall development in engine characteristics.
\end{abstract}

Keywords: chicken fat methyl ester; ferrous ferric oxide; compression ignition engine; performance and emission

\section{Introduction}

Increase in energy consumption is mounting hastily day-by-day, resulting in the excessive employment of fossil fuels leading to the depletion of fossil fuels, the degradation of the global environment, and an increase in fuel price. Only the transport sector consumed around $18.94 \%$ of total world energy use in 2012, and this will reach up to $28.33 \%$ in 2040 [1]. Fossil fuels are the product of high noxious gasses such as UHC (unburned hydrocarbon), SOx (sulphur oxides), CO (carbon monoxides), NOx (nitrogen oxides), PM (particulate matter) etc. [2]. These gasses debilitate the ozone layer by escalating GHG (greenhouse gases) levels. Almost 25\% of GHG are produced by the automotive sector, which should be earnestly noticed. Statistics reveal that $60 \%$ of GHG are discharged by small vehicles, $22 \%$ by medium and large vehicles, $8 \%$ by air transport, $4 \%$ by water transport, and $6 \%$ by others [3]. The depletion of fossil fuels and pollution concern associated with fossil fuels combustion have impelled several researchers to discover renewable fuel sources to substitute the conventional fossil fuels in compression ignition engines. Numerous 
researchers have intensely investigated several renewable bio-fuels, such as biodiesel, primary alcohol, vegetable oils, etc. Among the various renewable bio-fuels, biodiesel is a vastly conformed alternative fuel in compression ignition engines, owing to its finer physicochemical properties (high cetane number, bio-degradable, $>10 \%$ oxygen content, absence of sulfur and aromatic compound, high flash and fire temperatures, and excellent lubricity) than diesel fuel [4-8]. Despite having various incredible physicochemical properties, the commercialization of biodiesel in automotive sector is confined because of high density, impoverished atomization of fuel, poor oxidation stability, higher NOx emission, higher BSFC (brake specific fuel consumption), lower BTE (brake thermal efficiency), poor cold flow properties (high pour point, high cold filter plugging point (CFPP), and high cloud point), cold start problem, and sticking the piston ring $[9,10]$. These flaws can be sorted out by adopting the fuel adulteration method. The latest developed approaches for fuel adulteration are the use of oxygenated alcohols and nanoparticles as additives which may subsidiary to improve the compression ignition engine characteristics. However, the utilization of oxygenated alcohols as a fuel improver in compression ignition engine is very difficult, owing to lower cetane number, weak lubricating properties, and high auto-ignition temperature. The nanoparticles used display an exceptional effect on emission (NOx, CO, and UHC) reduction and performance (BTE and BSFC) improvement of an engine. Preceding investigations exposed that the incorporation of some amount of metal-oxide nanoparticles such as $\mathrm{Al}_{2} \mathrm{O}_{3}, \mathrm{Fe}_{3} \mathrm{O}_{4}, \mathrm{TiO}_{2}, \mathrm{Fe}_{2} \mathrm{O}_{3}, \mathrm{CNT}, \mathrm{ZnO}, \mathrm{MnO}, \mathrm{CeO}_{2}$, and $\mathrm{CuO}$ to neat fuel/blend displayed outstanding results in achieving the high BTE, lower BSFC, lower NOx, and lower carbonaceous emissions. Sarvestani et al. [11] developed novel nanoparticles (magnesium-iron mixed oxide) by introducing of $\mathrm{Mg}$ cations in $\mathrm{Fe}_{3} \mathrm{O}_{4}$ lattice through solution combustion method. The particles were utilized as emission reduction catalysts in turbocharged diesel engine by incorporating in coconut oil biodiesel blend. Resulting outcomes showed reduction in UHC by $57.4 \%$, CO by $1.6 \%$, and PM by $14.7 \%$, compared to coconut blend without additive. High surface area along with oxygen granting performance of nanoparticles enhances the combustion efficiency of coconut blend, which increased the combustion duration and resulted in the oxidation of carbon particles. NOx emission also decreased slightly for those nanoparticles. In a comparative study of Ozgur et al. [12], 5.6\%, 16.2\%, 18.9\%, and 22.1\% reductions in NOx were obtained for $\mathrm{ZnO}$ (50 ppm), $\mathrm{TiO}_{2}$ (100 ppm), $\mathrm{Fe}_{2} \mathrm{O}_{3}$ (100 ppm), Ni-Fe $\mathrm{O}_{4}$ (100 ppm) nanoparticles respectively. The catalytic effect of nanoparticles promotes the heat transfer in combustion chamber on account of their metallic-base structure which results in lower NOx. Shorter ignition delay encourages the development in A/F mixing resulting in oxygen deficit, which causes a significant reduction in the formation of NOx [13]. Rastogi et al. [14] conducted an experimental investigation to study the influence of $\mathrm{CuO}$ nanoparticles with jojoba biodiesel on engine behavior. The nanoparticles dispersed in jajoba biodiesel blend in amounts of $25 \mathrm{ppm}, 50 \mathrm{ppm}$, and $75 \mathrm{ppm}$. It was found that $75 \mathrm{ppm}$ infused fuel showed the maximum BTE (32.07\%) and diminish in UHC and CO emissions at apex load. However, a marginal increment in NOx observed for $\mathrm{CuO}$ infused fuels. Ali et al. [15] studied the engine attributes with WCO (waste cooking oil) blends together with $\mathrm{CeO}_{2}$ and $\mathrm{MgO}$ nanoparticles. Moreover, $30 \mathrm{ppm}$ each of $\mathrm{CeO}_{2}$ and $\mathrm{MgO}$ nanoparticles were incorporated into B20, B40 and B60 blends. The probing outcomes showed a steep rise in BTE and mechanical efficiency with substantial descends in BSFC. This would be credited to the catalytic effect of nanoparticles leading to superior evaporation which upgrades the atomization process, resulting in reduced ignition delay and absolute combustion of fuel. The escalation in cetane number and calorific value by admixing of nanoparticles in fuel also aids better engine efficiency [16]. In Gad and Jayaraj [17]'s comparative study, $\mathrm{Al}_{2} \mathrm{O}_{3}$, $\mathrm{TiO}_{2}$, and CNT nanoparticles were utilized with jatropha biodiesel blend in diesel engine to evaluate the performance and emission characteristics. Test results showed significant enhancement in performance and a steep reduction in emission for all nanoparticles. Particularly, maximum increment in BTE by $6.5 \%$ and reduction in EGT (exhaust gas temperature) by $27 \%$ were noted for $\mathrm{Al}_{2} \mathrm{O}_{3}$ blended fuel, maximum reduction in $\mathrm{CO}$ by $35 \%$, smoke by 
$50 \%$, and NOx by $62 \%$ was observed for CNT blended fuel, whereas maximum decrease in UHC by $22 \%$ was noticed for $\mathrm{TiO}_{2}$ blended fuel. Mujtaba et al. [18] investigated the impact of $\mathrm{TiO}_{2}$ and $\mathrm{CNT}$ nanoparticles as fuel additives and reported higher brake torque (BT) and higher brake power (BP) for CNT nanoparticles, and superior BTE and BSFC for $\mathrm{TiO}_{2}$ nanoparticles. Engine emissions such as UHC and $\mathrm{CO}$ were less for TiO2 fuel additive, whereas NOx emission was inferior for CNT nanoparticles. High latent heat of evaporation because of the presence of nanoparticles stimulates the oxidation reaction of carbon particles that caused momentous decrease in engine emission [19]. Muthusamy et al. [20] utilized the $\mathrm{Fe}_{3} \mathrm{O}_{4}$ nanoparticles (50 ppm, $100 \mathrm{ppm}$ ) with pongamia oil methyl ester blend in the compression ignition engine. Results showed noticeable enhancement in BTE, reduction in BSFC, and substantial reduction in $\mathrm{UHC}$, smoke, and CO emissions. Similar kinds of results were recorded by Aalam [21] for $\mathrm{Al}_{2} \mathrm{O}_{3}$ and $\mathrm{Fe}_{3} \mathrm{O}_{4}$ nanoparticles. Wu et al. [22] doped $30 \mathrm{ppm}$ carbon coated aluminum nanoparticles in biodiesel blends to examine the attributes of engine. The results showed considerable drop in BSFC by $6 \%$, steep drop in NOx, CO, and UHC emissions by $6 \%, 19 \%$ and $14.5 \%$ respectively. The particles instigate the hydrocarbon and oxygen reaction, whereas they reduce the nitrogen and oxygen reactions, leading to low NOx formation. Higher hydrocarbon and oxygen reaction ascribe to the complete burning of fuel which declines the $\mathrm{CO}$ and UHC formation [23]. The admixing of nanoparticles decreased the fuel consumption and enhanced the engine efficiency because they performed as a secondary energy carrier in fuel, which improves the combustion process by providing the surface energy during combustion [24,25].

\section{Motivation and Objective of the Study}

India is the second highest populated nation in the world, and there is a continually mounting the demand for fossil fuels. To decrease the dependence on foreign fuels, government of India immensely recommends the application of biodiesel as an alternate fuel source. Besides, India is at 5 th position in the world in producing poultry meat, hence millions of tons of waste are produced per day from the poultry industry, which consist of a massive amount of chicken fat. According to statistics of the government of India, every year almost 77,000 tons of chicken fat are thrown away because the presence of unfavorable cholesterol and trans-fat in it create a nuisance for demos [26]. Therefore, the authors selected the waste chicken fat as a biodiesel feedstock acquired from the local chicken meat market. Only few investigators reported the utilization of waste chicken fat as alternative fuel source in a compression ignition engine. However, earlier studies highlighted the homology of waste chicken fat as a coherent source for compression ignition engine [27]. Nevertheless, in the present study, chicken fat methyl ester (CFME) is employed in calibrated compression ignition engine and it demonstrated the insignificant descend in engine performance and substantial descend in exhaust emissions. However, high surface tension, high density and high viscosity of chicken fat methyl ester degraded the properties of the blend fuel. Besides, chicken fat methyl ester also suffers from poor cold flow properties, cold climate starting of compression ignition engine, and higher NOx. The addition of nanoparticles as additive in blend fuel can overcome all these drawbacks and improve the cetane number, calorific value, heat transfer properties of fuel, micro-explosion phenomenon, reduction in ignition delay period, etc.; many investigators incorporated the nano-additives in different biodiesel [22,24,25]. The previous literature proposed that there is no study available on the application of ferrous ferric oxide (FFO) nanoparticles as fuel additive in chicken fat methyl ester blend in compression ignition engine. Hence, there exists a research gap, and to fulfil this research gap, a comprehensive investigation needs to be carried out on engine emissions (CO, UHC, NOx, smoke) and performance (BTE, BSFC, BSEC, EGT) characteristics and compared with non-additives blended fuels. Hence, the influence of nanoparticles (FFO nano-additive) with pure diesel-biodiesel blends on compression ignition engine emission and performance characteristics are carried out. The core objective of this study is to make a promising sustainable fuel which has the capability to descend the engine emission with improving the performance. 


\section{Materials and Methods}

\subsection{Biodiesel Preparation}

The waste chicken fat is collected from a local chicken market and cleanse with tap water to oust all impurities. The chicken fat oil is extracted from waste chicken fat by heating $\left(100-110^{\circ} \mathrm{C}\right)$ it and subsequent oil is filtered using sieve to separate the muscles. Figure 1 showing filtered chicken fat oil and its composition is reported in Table 1 . This fat oil cannot be used directly in the compression ignition engine because of its high viscosity, high density, and low volatility. Exorbitant viscosity and greater density are liable to poor atomization and excessive penetration of fuel spray, because of which certain hindrances such as piston ring sticking, engine deposits, thickening and gelling of lubricating oil, and coking and trumpet formation on injector, take place [28,29].

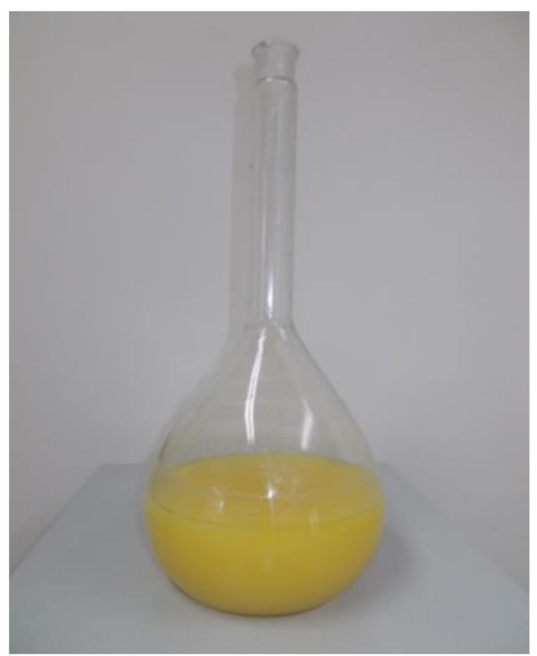

Figure 1. Filtered chicken fat oil.

Table 1. Fatty acid compositions of chicken fat oil.

\begin{tabular}{cccc}
\hline Fatty Acid Composition & Carbon Number & Chemical Formula & Wt.(\%) \\
\hline Myristic & $\mathrm{C} 14: 0$ & $\mathrm{C}_{14} \mathrm{H}_{28} \mathrm{O}_{2}$ & 0.74 \\
Palmitic & $\mathrm{C} 16: 0$ & $\mathrm{C}_{16} \mathrm{H}_{32} \mathrm{O}_{2}$ & 22.30 \\
Palmitioleic & $\mathrm{C} 16: 1$ & $\mathrm{C}_{16} \mathrm{H}_{30} \mathrm{O}_{2}$ & 8.19 \\
Stearic & $\mathrm{C} 18: 0$ & $\mathrm{C}_{18} \mathrm{H}_{36} \mathrm{O}_{2}$ & 5.40 \\
Oleic & $\mathrm{C} 18: 1$ & $\mathrm{C}_{18} \mathrm{H}_{34} \mathrm{O}_{2}$ & 42.47 \\
Linoleic & $\mathrm{C} 18: 2$ & $\mathrm{C}_{18} \mathrm{H}_{32} \mathrm{O}_{2}$ & 19.30 \\
Linolenic & $\mathrm{C} 18: 3$ & $\mathrm{C}_{18} \mathrm{H}_{30} \mathrm{O}_{2}$ & 1.02 \\
Eicosenoic & $\mathrm{C} 20: 1$ & $\mathrm{C}_{20} \mathrm{H}_{38} \mathrm{O}_{2}$ & 0.43 \\
\hline
\end{tabular}

In current work, the transesterification method is adopted to detract that exorbitant viscosity of triglycerides. Amyl alcohol, butanol, ethanol, methanol, and propanol are the prevalent alcohols that can be utilizied in the transesterification process. In these alcohols, methanol is more desirable because of its polar group and shortest hydrocarbon chain, which makes the separation and purification steps of biodiesel easier [30]. The transesterification reaction can be performed with three kinds of catalysts, such as alkalis, acids, and enzymes catalyst. Catalyst selection for the transesterification reaction relies upon the percentage amount of FFA (free fatty acid) content in triglycerides. If the amount of FFA\% content in triglyceides is $\leq 1$, then the base catalyst is more apposite or else acid catalyst [28]. However, enzymes catalyst can be used with any amount of FFA\%, but due to slow reaction rate, difficulty in biodiesel separation step, and pricey, researchers do not prefer this in transesterification reaction. The rate of transesterification reaction for 
base catalyst is thousands times higher than acid catalyst. The amount of FFA\% content in triglycerides is calculated by the following Equation:

$$
\text { FFA } \%=\text { Acid value }(\mathrm{AV}) * 0.503
$$

Acid value (AV) mentioned in Equation (1) is measured through titration reaction by using the following Equation:

$$
\mathrm{AV}=(\mathrm{mL} \text { of } \mathrm{KOH} * \text { normality }(\mathrm{N}) \text { of } \mathrm{KOH} * \text { molecular mass of } \mathrm{KOH}) /(\text { weight of sample })
$$

Moreover, $0.1 \mathrm{~N} \mathrm{KOH}$ solution, chicken fat oil, and absolute ethanol alcohol are utilized in titration reaction to compute the AV from Equation (2). AV obtained from Equation (2) is $1.065 \mathrm{mg} \mathrm{KOH} / \mathrm{g}$ and FFA\% acquired from Equation (1) is 0.536, therefore base catalyst is opted for transesterification reaction. $\mathrm{KOH}$ (potassium hydroxide), as a base catalyst, is the most suitable catalyst in performing the transesterification reaction [31], therefore it is used in this work.

Hotplate magnetic stirrer-assisted transesterified biodiesel is produced from chicken fat oil. Homogeneous base transesterification reaction is carried out on hotplate magnetic stirrer under the following operating conditions: methanol to chicken fat oil molar ratio (6:1), amount of $\mathrm{KOH}$ catalyst $(0.85 \mathrm{wt} . \%)$, reaction temperature $\left(60^{\circ} \mathrm{C}\right)$, stirring speed $(850 \mathrm{rpm})$, and reaction time $(60 \mathrm{~min})$. After completion of the reaction, the resulting solution is relocated into a separating funnel and leaves it for $6 \mathrm{~h}$ to isolate chicken fat methyl ester from glycerine. Since glycerine density is greater than biodiesel, the solution in the separating funnel is divided into two layers. The lower layer in separating funnel is of glycerine, whereas the upper layer is of biodiesel. Lower layer (glycerine) is segregated from the separating funnel by opening the stopcock. The obtained biodiesel is not in pure form because contains a catalyst and methanol. In order to depose residual catalyst and excess alcohol, obtained biodiesel is washed three times with distilled water. Eventually, the washed biodiesel is heated above $100{ }^{\circ} \mathrm{C}$ to get rid of the remaining water content from it. The resulting biodiesel is in a neat and pure form which is ready to use. Figure 2 displayed the pure CFME/biodiesel and Figure 3 illustrated the flow chart of biodiesel synthesis process. The various properties of pure CFME/biodiesel and pure diesel are mentioned in Table 2.

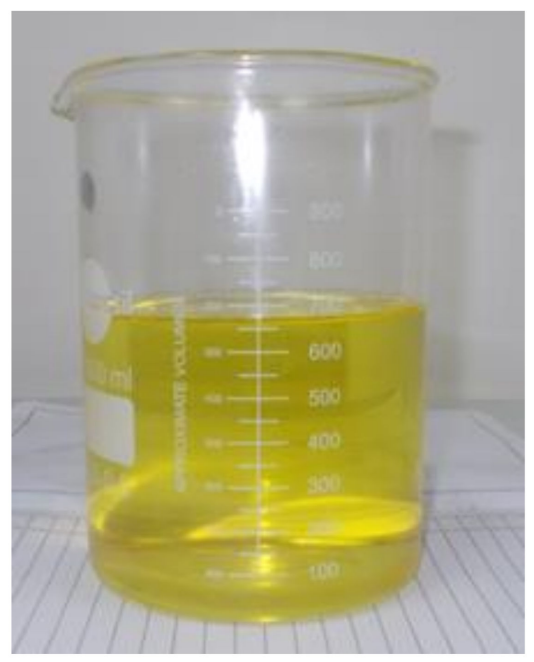

Figure 2. Neat chicken fat methyl ester. 


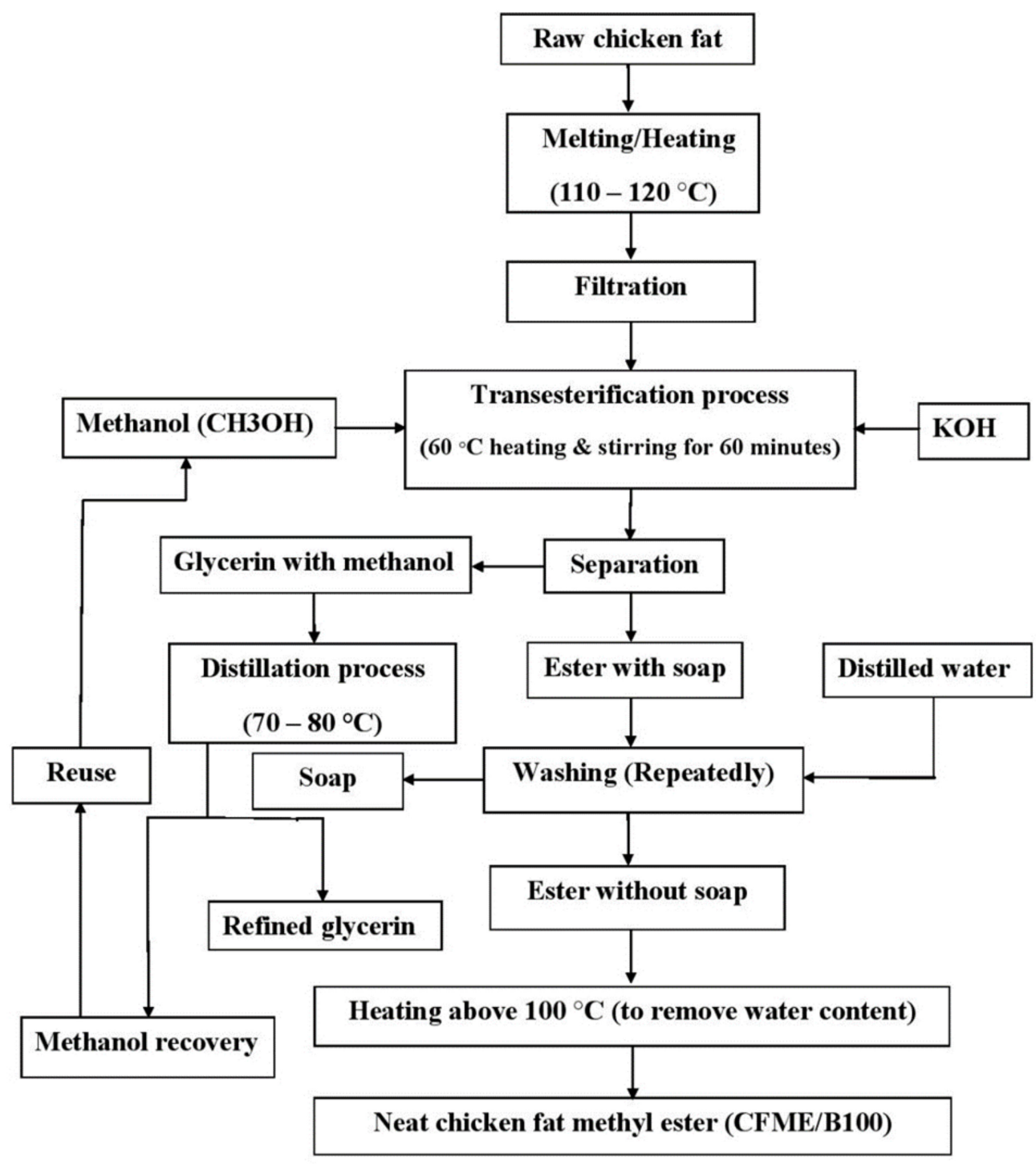

Figure 3. Flow chart of biodiesel synthesis.

Table 2. Properties of pure diesel (PD), Chicken fat methyl ester/biodiesel (CFME), CFME blends and nano-additive fuels.

\begin{tabular}{ccccccc}
\hline Notations & $\begin{array}{c}\text { Density } \\
(\mathbf{g} / \mathbf{c c})\end{array}$ & $\begin{array}{c}\text { Viscosity } \\
(\mathbf{c S t})\end{array}$ & $\begin{array}{c}\text { Flash } \\
\text { Point }\left({ }^{\circ} \mathbf{C}\right)\end{array}$ & $\begin{array}{c}\text { Fire Point } \\
\left({ }^{\circ} \mathbf{C}\right)\end{array}$ & $\begin{array}{c}\text { Cetane } \\
\text { Value }\end{array}$ & $\begin{array}{c}\text { Calorific } \\
\text { Value (MJ/kg) }\end{array}$ \\
\hline PD & 0.840 & 2.58 & 71 & 75 & 46.0 & 43 \\
CFME & 0.8754 & 4.94 & 160 & 170 & 57.8 & 40.427 \\
B10 & 0.8435 & 2.81 & 80 & 85 & 47.2 & 42.742 \\
B20 & 0.8479 & 3.05 & 89 & 94 & 48.4 & 42.485 \\
B30 & 0.8507 & 3.29 & 98 & 103 & 49.5 & 42.228 \\
B10FFO50 & 0.8443 & 2.85 & 78 & 82 & 49.2 & 43.020 \\
B20FFO50 & 0.8483 & 3.09 & 87 & 92 & 50.3 & 42.761 \\
B30FFO50 & 0.851 & 3.33 & 94 & 101 & 51.4 & 42.502 \\
B10FFO100 & 0.8449 & 2.89 & 77 & 81 & 50.5 & 43.319 \\
B20FFO100 & 0.8488 & 3.13 & 85 & 90 & 51.7 & 43.059 \\
B30FFO100 & 0.8518 & 3.37 & 91 & 97 & 52.8 & 42.798 \\
B10FFO150 & 0.8457 & 2.95 & 78 & 82 & 52.0 & 43.250 \\
B20FFO150 & 0.8492 & 3.18 & 86 & 91 & 53.4 & 42.980 \\
B30FFO150 & 0.8527 & 3.54 & 93 & 98 & 54.6 & 42.719 \\
\hline
\end{tabular}




\subsection{Ferrous Ferric Oxide (FFO) Nano-Fuel Additives}

FFO nanoparticles are colloidal compounds of iron and oxygen that exhibit high surface reactivity, non-toxicity, high free energy, and super paramagnetic properties at ambient conditions. Due to the attractive properties of FFO nanoparticles, pioneers are interesting to utilize them in many fields, such as catalysis, ferro-fluid, biosensors, and magnetic separations. For this study, FFO nanoparticles are taken from the chemistry lab of Jamia Millia Islamia, India. The chemical composition and crystallite size of FFO can be determined by XRD (X-ray diffraction) analysis. The analysis is carried out using of Philips-X'pert MPD X-ray diffractometer, which is operated under the following conditions; $1.5404 \AA$ X-ray wavelength of $\mathrm{Cu}-\mathrm{K} \alpha$ radiation, $20^{\circ}-70^{\circ}$ angle $(2 \theta)$ range with $0.05^{\circ}$ step size, $40 \mathrm{kV}$ and $40 \mathrm{~mA}$. Figure 4 showed the XRD pattern of the FFO nanoparticles. From Figure 4, it is explicitly noticed that prominence diffraction peaks of the (111), (220), (311), (400), (422), and (511) crystallographic planes are attained at $2 \theta=21.32^{\circ}, 35.47^{\circ}, 41.93^{\circ}$, $50.72^{\circ}, 63.51^{\circ}$, and $68.39^{\circ}$ respectively. Besides these diffraction peaks, no further peak has been noticed which unfolds the formation of pure and single-phase without any impurity and agglomeration. The diffraction peaks of FFO's XRD patterns are nicely matched with the standard FFO's XRD spectra reported in JCPDS file (file no: 75-0033), which ratified the crystallographic system of cubic structure. Moreover, it is also seen that peaks are exceptionally broad and narrow, which signifies the formation of enormously fine particles in nano-scale range. Therefore, it can be concluded that FFO nanoparticles have high crystallinity and high purity. The crystallite size can be computed by using Debye-Scherer's formula, which is given below;

$$
\mathrm{D}=\mathrm{K} \lambda / \beta \cos (\theta)
$$

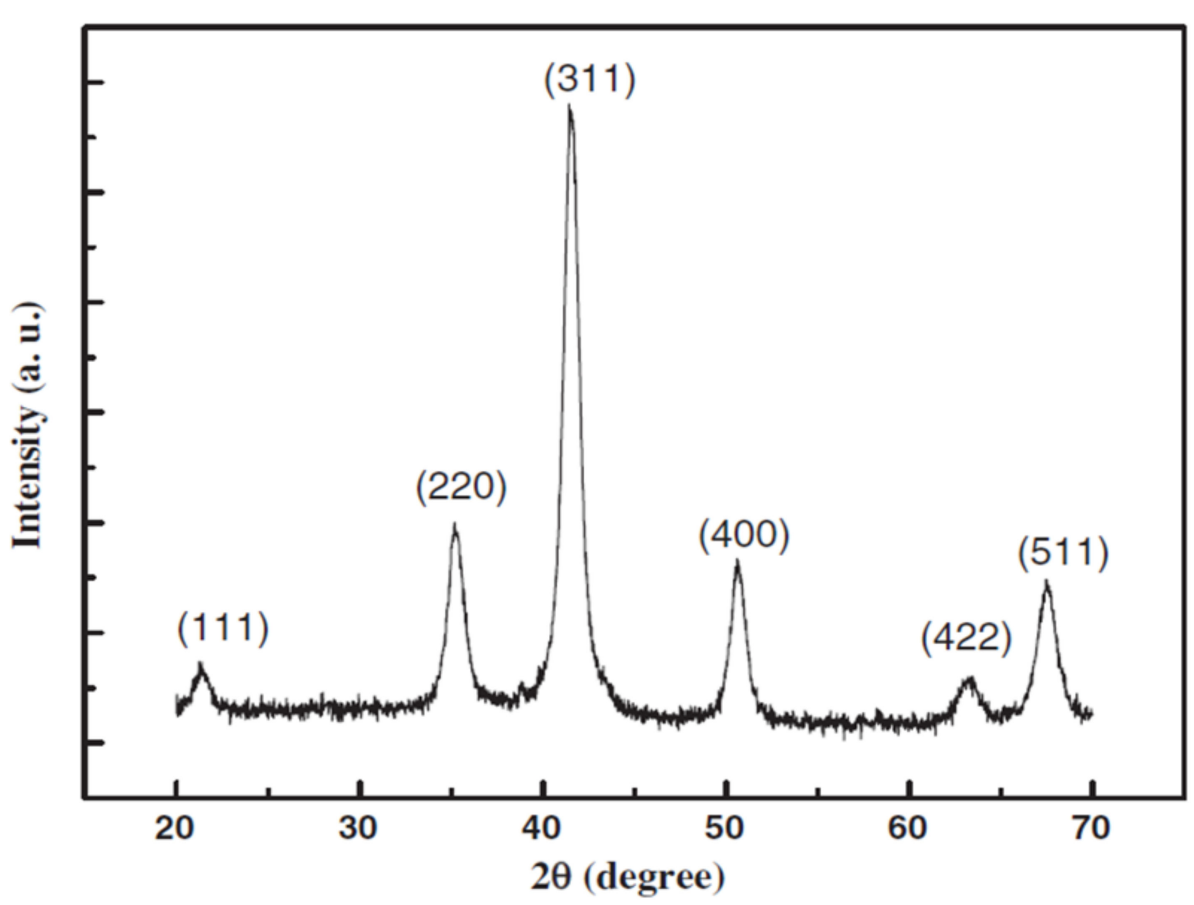

Figure 4. XRD pattern of ferrous ferric oxide (FFO) nanoparticles.

In Equation (3), $\mathrm{D}$ is the average crystallite size $(\mathrm{nm}), \mathrm{K}$ is Scherrer constant $=0.94, \lambda$ is $\mathrm{Cu}-\mathrm{K} \alpha$ wavelength $=1.5404 \AA(0.15404 \mathrm{~nm}), \beta$ is the full width at half maximum of peak (radian) at $2 \theta$, and $\theta$ is Bragg angle or diffraction angle. From Equation (3) calculation, the mean crystallite size of FFO nanoparticles is $18.21 \mathrm{~nm}$.

Morphology and average size of FFO nanoparticles are analyzed by using TEM (transmission electron microscopy) analysis. TEM analysis is carried out on Philips-EM208S TEM equipped with a digital camera and operated at $100 \mathrm{kV}$ of an accelerating voltage. 
TEM image with two different magnifications of FFO nanoparticles is illustrated in Figure 5. From Figure 5, it can be observed that FFO nanoparticles are extremely small (nm size) with the homogeneous particles size distribution. Besides, it can be noticed that the majority of FFO nanoparticles have a spherical shape without aggregation. A histogram of particle size distribution is displayed in Figure 6, which is plotted in accordance with the size of 70 FFO nanoparticles. The mean crystallite size is found to be $14.8 \mathrm{~nm}$ with a standard deviation of $1.8 \mathrm{~nm}$. Conversely, $18.21 \mathrm{~nm}$ average size of FFO nanoparticles was obtained from XRD analysis. This distinction in crystallite size results in the expression of the size distribution between $11 \mathrm{~nm}$ and $20 \mathrm{~nm}$.

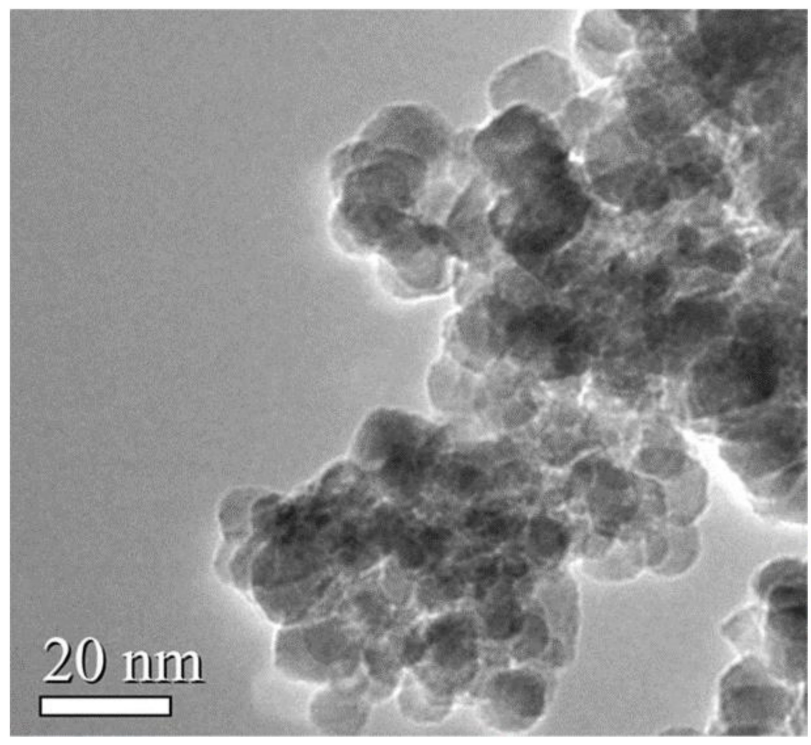

Figure 5. TEM image of FFO nanoparticles with two different magnifications.

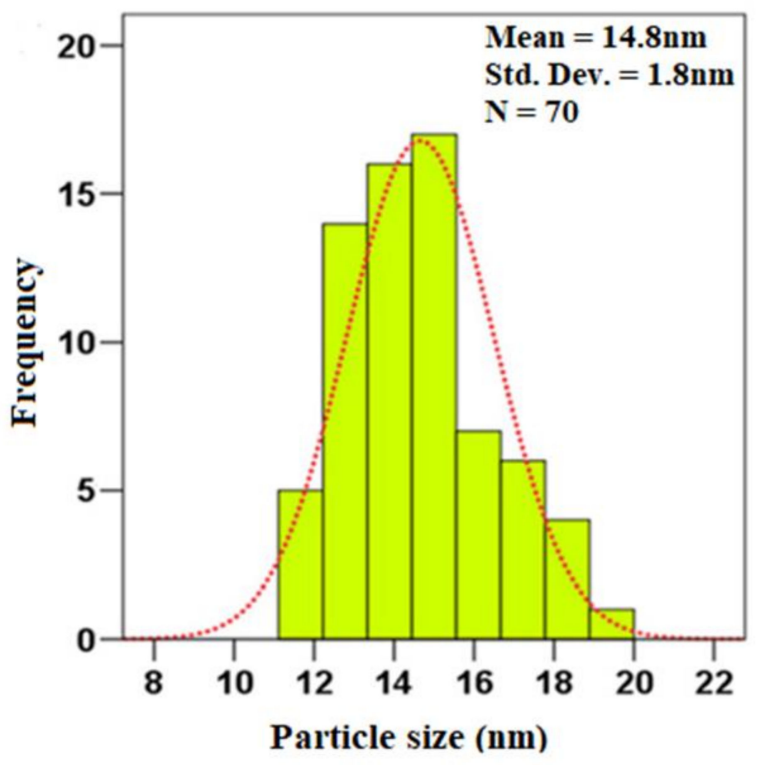

Figure 6. Histogram of particles size distribution.

\subsection{Preparation of Fuel Samples}

XRD and TEM analyses exposed that size distribution of FFO nanoparticles lies between $11 \mathrm{~nm}$ and $20 \mathrm{~nm}$. The sizes of FFO nanoparticles are vastly less compared to the diameter of the fuel injector nozzle, therefore these particles would not create any hurdle to fuel flow inside the fuel injector nozzle. A standard nano-fuel preparation 
method is followed for the dispersion of FFO nanoparticles into the blends (pure diesel + CFME/biodiesel), in order to acquire the better-quality solubility of nanoparticles in blended fuel. At first, neat, synthesized biodiesel in the amount of 10 vol. $\%, 20$ vol.\%, and $30 \mathrm{vol} . \%$ is manually mixed with pure diesel and formed blends assigned as B10, $\mathrm{B} 20$, and B30 respectively. Afterwards, FFO nanoparticles in order of 50 ppm, 100 ppm, and $150 \mathrm{ppm}$ are weighted by using a digital precise weighing machine. Each weighted quantity of FFO nanoparticles are dispersed one by one into B10, B20, and B30, which are assigned as B10FFO50, B10FFO100, B10FFO150, B20FFO50, B20FFO100, B20FFO150, B30FFO50, B30FFO100, and B30FFO150. Following the dispersion of FFO nanoparticles, fuels are sonicated by using an ultrasonicator for inhibiting the nanoparticles aggregation and attaining the good stable solution with better suspension. The ultrasonication process is carried out on titanium horn probe ultrasonicator operated at $50-60 \mathrm{kHz}$ frequency, $1 \mathrm{~kW}$ of ultrasonicator power, $220-240 \mathrm{~V}$ AC current, and 10-40 min duration period. The sonicated fuel samples are stored in an opaque test tube for the examination of suspension quality. It is noticed that a higher stable suspension of FFO nanoparticles in blends found when the sonication process is performed for $30 \mathrm{~min}$. The physicochemical properties of reformulated nano-additive fuels are illustrated in Table 2.

\subsection{Experimental Setup and Methodology}

A 1-cylinder, naturally aspirated, 4-stroke, DICI (direct injection compression ignition) engine is used for evaluating the performance and emission characteristics of various biodiesel blends and reformulated nano-additive fuels. The scientific specifications of DICI engine used for experimentation are listed in Table 3 and the schematic sketch of complete engine setup is presented in Figure 7. The DICI engine is joined with an AG10 eddy current dynamometer, which is used for shifting the engine load with the aid of CLTC (closed-loop torque controller). Mars multi-gas analyzer and smoke meter are utilized to record the concentrations of $\mathrm{CO}, \mathrm{UHC}, \mathrm{NOx}$, and smoke in the exhaust of an engine. K-type thermocouples are connected to the exhaust pipe of an engine for measuring the EGT (exhaust gas temperature).

Table 3. Specifications of direct injection compression ignition (DICI) engine set up.

\begin{tabular}{cc}
\hline Parameters & Specifications \\
\hline Type/Configuration & Vertical, 4-stroke diesel engine, totally enclosed \\
Make & Kirloskar \\
Model & TV 1 \\
No. of cylinders & One \\
Type of Ignition & Compression ignition \\
Type of cooling & Water cooled \\
Rated power & $3.5 \mathrm{~kW}$ @ $1500 \mathrm{rpm}$ \\
Bore x stroke & $87.5 \mathrm{~mm} \times 110 \mathrm{~mm}$ \\
Crank radius & $55 \mathrm{~mm}$ \\
Connecting rod length & $234 \mathrm{~mm}$ \\
Variable compression ratio & $76 \mathrm{bar}$ \\
Peak pressure & $661 \mathrm{cc}$ \\
Swept volume & $40.1 \mathrm{cc}$ \\
Clearance volume & $34.0 \mathrm{cc}$ \\
Cavity volume at piston top & 12:1 to 18.5:1 (standard compression ratio: 17.5) \\
Combustion system & $200 \mathrm{bar}$ \\
Injection pressure & $23^{\circ} \mathrm{CA} \mathrm{bTDC}$ \\
Injection timing & Hemispherical shape \\
Combustion chamber & $20 \mathrm{~mm}$ \\
Orifice diameter & $0.3 \mathrm{~mm}$ \\
Nozzle orifice diameter & Natural aspiration \\
Aspiration &
\end{tabular}




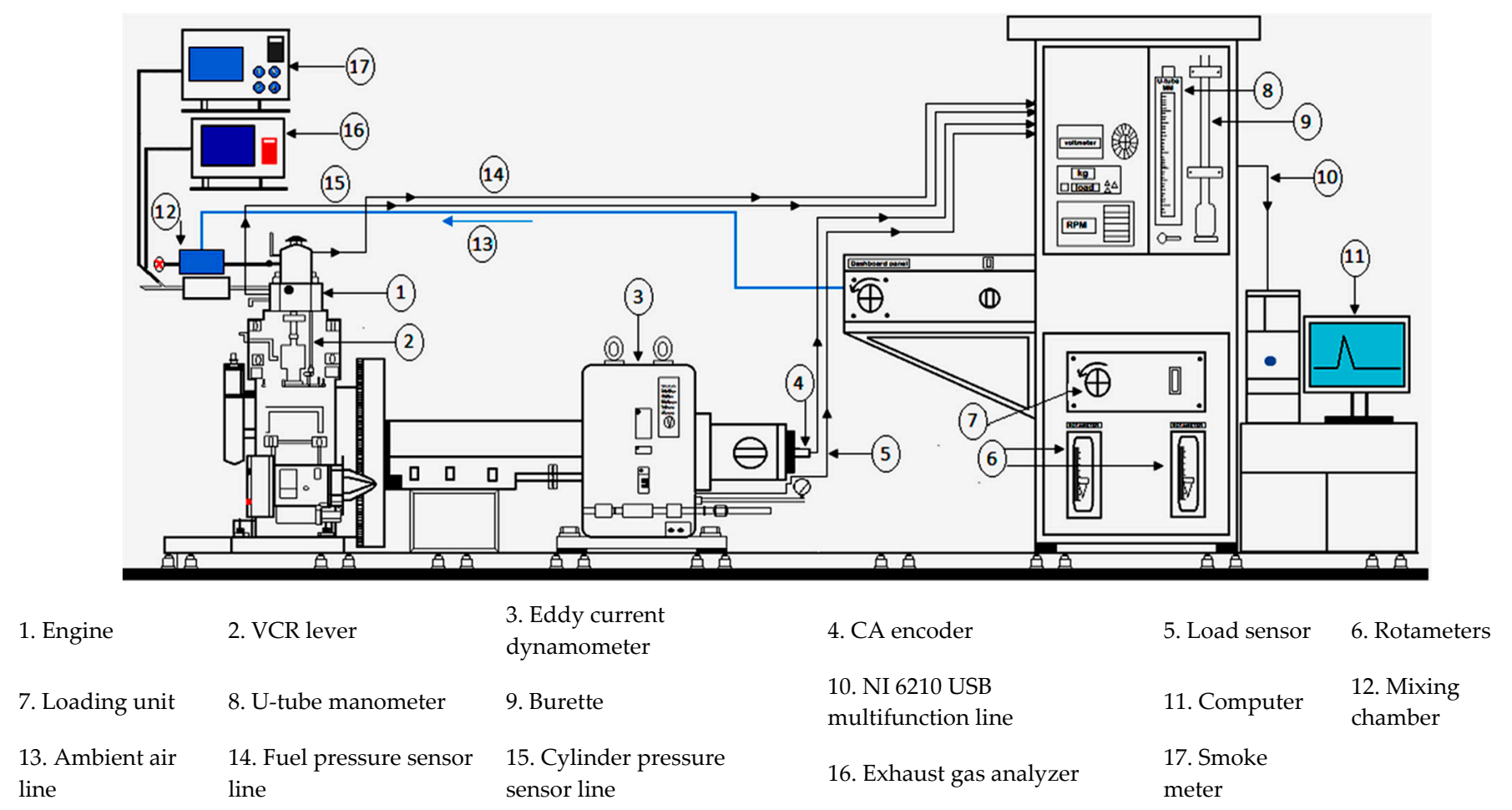

Figure 7. Schematic layout of experimental setup.

The present work was devoted to investigating the emission and performance characteristics of compression ignition engine by using chicken fat methyl ester blended with FFO nanoparticles. The experimental process is divided into two phases; in the first phase, nonnano-additive fuels (pure diesel, B10, B20, and B30) are used to run the engine, whereas in the second phase, nano-additive fuels are used. Initially, the compression ignition engine is permitted to run with neat diesel as base fuel and then fuelled with chicken fat methyl ester blends (B10, B20, and B30) under various loads at a constant speed of $1500 \mathrm{rpm}$. Emission and performance data for non-nano-additive fuels are recorded under steady state condition of the engine. Thereafter, compression ignition engine is operated for all nano-additive fuels (B10FFO50, B10FFO100, B10FFO150, B20FFO50, B20FFO100, B20FFO150, B30FFO50, B30FFO100, and B30FFO150) under the identical conditions as for non-nano-additive fuels and recorded all values. For nano-additive fuels, emission and performance data are also noted under steady state condition of engine. All the tested fuels are injected at an injection pressure of 200 bar and compression ratio of 17.5:1, with injection timing of $23^{\circ} \mathrm{bTDC}$. Eventually, all the investigational results of FFO nano-fuels are compared with the non-nano-additive fuels.

Percentage relative uncertainty for engine parameters (BSFC, BTE, CO, UHC, NOx, smoke, EGT) is determined through different equipment uncertainties. The summary of uncertainty analysis of investigated values and measured parameters is given in Table 4. The overall uncertainty of experiments is calculated by the following formula:

Overall uncertainty $=\sqrt{ }\left\{\right.$ uncertainty $\%$ of $\left.\left(\mathrm{BP}^{2}+\mathrm{BTE}^{2}+\mathrm{BSFC}^{2}+\mathrm{CO}^{2}+\mathrm{UHC}^{2}+\mathrm{NOx}^{2}+\mathrm{smoke}^{2}+\mathrm{EGT}^{2}\right)\right\}$ $=\sqrt{ }\left(0.5^{2}+0.4^{2}+0.4^{2}+1.5^{2}+1.4^{2}+1.5^{2}+0.9^{2}+0.8^{2}\right)= \pm 2.91 \%$

The overall uncertainty is $\pm 2.91 \%$ for measured parameters and it is within the allowable limit [3]. 
Table 4. List of measurement range, accuracy and percentage uncertainty.

\begin{tabular}{cccc}
\hline Parameters & Measurement Range & Accuracy $( \pm$ ) & \% Uncertainty \\
\hline Speed $(\mathrm{rpm})$ & $0-10000$ & \pm 10 & \pm 0.1 \\
Load $(\mathrm{Nm})$ & $0-500$ & \pm 0.1 & \pm 0.2 \\
Time (s) & - & \pm 0.2 & \pm 0.2 \\
BP $(\mathrm{kW})$ & $0-50$ & & \pm 0.3 \\
BTE (\%) & - & \pm 5 & \pm 0.4 \\
BSFC (g/kw.h) & - & \pm 0.03 & \pm 0.4 \\
CO (\% vol.) & $0-10$ & \pm 5 & \pm 1.5 \\
UHC (ppm) & $0-2000$ & \pm 10 & \pm 1.4 \\
NOx (ppm) & $0-5000$ & \pm 1 & \pm 1.5 \\
Smoke (HSU) & $0-100$ & \pm 2 & \pm 0.9 \\
EGT $\left({ }^{\circ} \mathrm{C}\right)$ & $0-400$ & & \pm 0.8 \\
\hline
\end{tabular}

\section{Result and Discussion}

\subsection{Carbon Monoxide (CO) Emission}

Figure 8 shows the effect of $\mathrm{CO}$ emission with BMEP (brake mean effective pressure) for all tested fuels. It is seen from figure that $\mathrm{CO}$ emission is lower at part BMEP and higher at maximum BMEP, because when engine components are moving at high inertia, then time is very less for homogeneous mixing of $\mathrm{A} / \mathrm{F}$ molecules, thus resulting in incomplete combustion at high BMEP [32]. In general, $\mathrm{CO}$ emission is the outcome of inadequate combustion of fuel which happens predominantly due to the oxygen shortage during combustion. Based on outcomes, $\mathrm{CO}$ emission of tested fuels can line up as PD $>$ CFME blends $(\mathrm{B} 10>\mathrm{B} 20>\mathrm{B} 30)>$ nano-additive fuels $(50 \mathrm{ppm}>150 \mathrm{ppm}>100 \mathrm{ppm})$. CO emission is lower for all CFME blends at all BMEP compared to those PD fuels, because oxygen content in PD is zero whereas 10-12 wt.\% of oxygen present in CFME. Thus, combustion mechanism of CFME blends is superior to those PD fuels, resulting in lower $\mathrm{CO}$ emission for CFME blends. Among CFME blends, $\mathrm{B} 30$ provide better $\mathrm{CO}$ emission results which are $0.132 \%, 0.149 \%, 0.177 \%, 0.21 \%$ vol. obtained at $1.03 \mathrm{bar}, 2.06 \mathrm{bar}, 3.10 \mathrm{bar}$, and $4.13 \mathrm{bar}$ BMEP respectively.

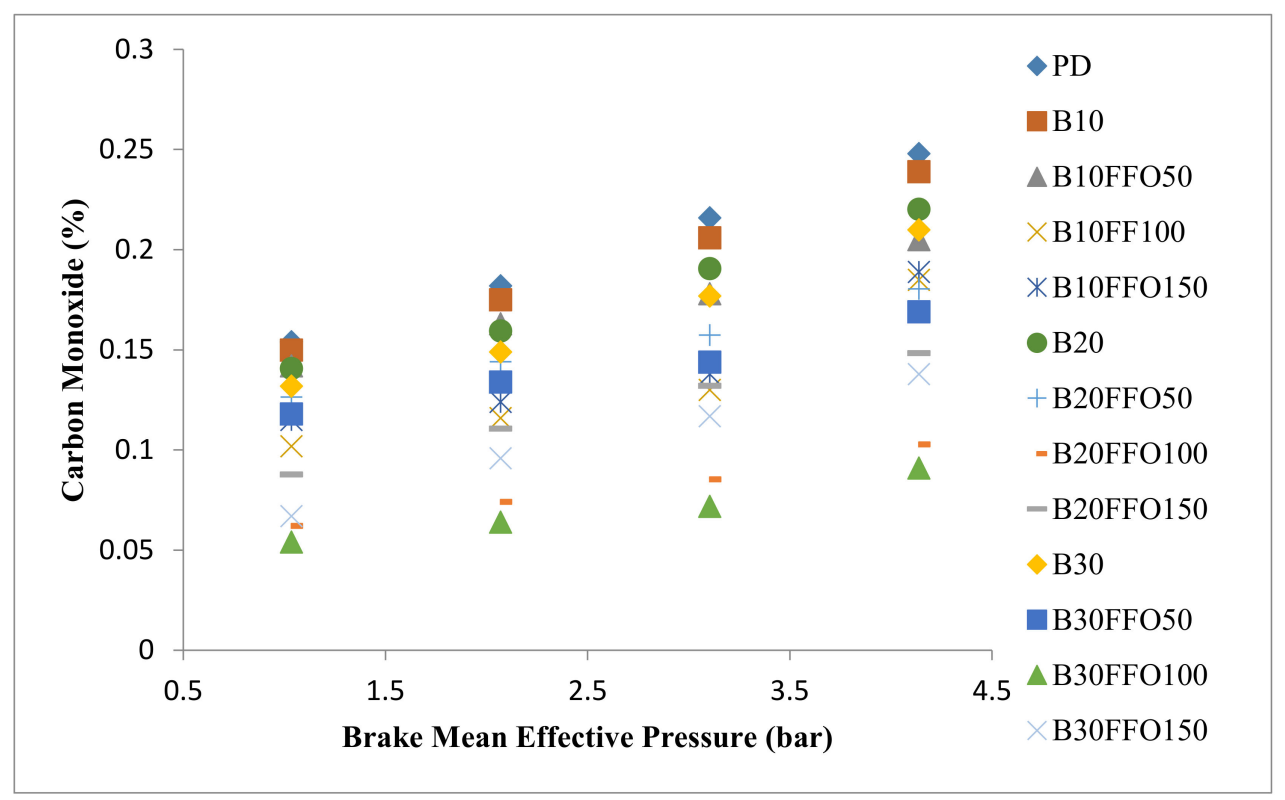

Figure 8. Comparison of carbon monoxides (CO) with brake mean effective pressure (BMEP).

Percentage volume of $\mathrm{CO}$ emission is further reduced for all CFME blends when different concentrations of FFO nanoparticles introduced into those blends. Decrease in $\mathrm{CO}$ emission with FFO nanoparticles doped fuels may be because of decomposition of FFO 
into $\mathrm{Fe}$ and $\mathrm{O}$ atoms during the combustion process. Fe atoms enhanced the heat transfer between flame front and unburned fuel particles due to high thermal conductivity whereas $\mathrm{O}$ atoms encouraged the oxidation of fuel vapors in reaction zone. This facilitates the high reaction rates and high flame temperature due to which unburned fuel particles are burnt in a shorter time. A small amount of Fe atoms in the reaction zone can enhance the combustion rate of $\mathrm{CO}$. In addition, FFO particles develop condensation sites in reaction zone as a result in oxidation of $\mathrm{CO}$ to $\mathrm{CO} 2$, hence the decrease in $\mathrm{CO}$ formation [33]. $\mathrm{B} 30$ blend with FFO nanoparticles gave minimum $\mathrm{CO}$ emission corresponding to other nanofuels. CO emission for B30FFO50 is reduced by $19.52 \%$ corresponding to B30 at 4.13 bar BMEP, similarly reduction followed by $56.66 \%$ for B30FFO100 and 34.28\% for B30FFO150.

Highest reduction in CO emission is achieved for B30FFO100 fuel among all fuels at peak BMEP. From $\mathrm{CO}$ emission investigational results, $\mathrm{CO}$ emission dropped for all nano-additive fuels as the quantity of FFO nanoparticles in fuel increased up to $100 \mathrm{ppm}$. For higher quantity (150 ppm), it increased slightly, attributed to the rise in agglomeration rate of nanoparticles which leads to a diminution in overall surface area for catalytic activity [34]. A similar observation for CO emission was reported by Khan et al. [35].

\subsection{Unburned Hydrocarbon (UHC) Emission}

Fuel mostly contained hydrocarbons, which are oxidized into $\mathrm{CO} 2$ and water vapor when it combusted completely during combustion; such combustion can be classified as an exothermic combustion reaction. Uncombusted or partially combusted reactions produce UHC emission, which is more influenced because of the non-homogeneous mixing of fuel and air than corresponding to A/F equivalence ratio [36]. Figure 9 displayed the disparities in UHC emission at different BMEP for all fuel samples. It can be seen from the figure that UHC emission mounting with escalate in BMEP for all fuels because a higher quantum of fuel participated in combustion without change in air quantity within the cylinder, resulting in a rich mixture at high BMEP thus liberating higher UHC emission. It can also be seen from the figure that all CFME blends produced lower UHC emission than $\mathrm{PD}$, owing to the substantial quantum of $\mathrm{O} 2$ inbuilt in CFME blends, aiding in sustaining the combustion, therefore resulting in inferior UHC emission for CFME blends [37]. Like $\mathrm{CO}$ emission, B30 produced lowest UHC emission among non-additive tested fuels. UHC emission for B30 blend at 1.03 bar, 2.06 bar, 3.10 bar and 4.13 bar of BMEP was found to be 36 ppm, 39 ppm, 40 ppm, and 44 ppm respectively.

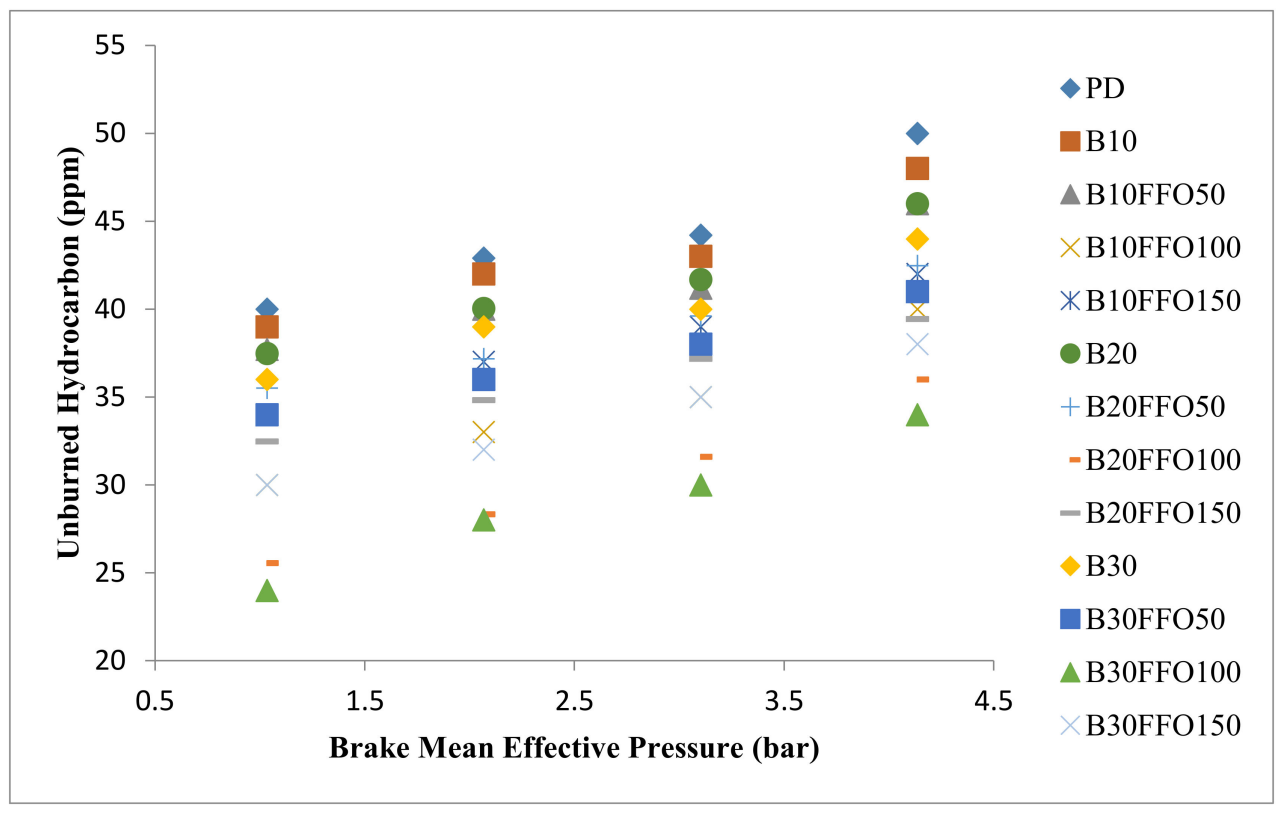

Figure 9. Comparison of UHC with BMEP. 
Reformulated CFME blends by the dilution of FFO nanoparticles showed the significant diminution in UHC emission collated to non-additive CFME blends, as depicted in Figure 9. Similar to CO emission observation, 100 ppm quantity of FFO nanoparticles was found to be optimum for UHC emission reduction. Then, it is obvious that B30FFO100 grants the superior lessening in UHC emission among all tested fuels. At full BMEP, 6.81\%, $22.72 \%$, and $13.63 \%$ decrements are observed in UHC emission for B30FFO50, B30FFO100, and B30FFO150 collated to B30 blend. The reason behind this significant decrement is the large reactive surface of FFO nano-additive with high thermal conductivity enhances the oxidation of unburned fuel particles (more complete combustion), thus lesser possibility for the formation of rich mixture region; hence, it generates lesser UHC emission [36,37]. However, reduction in UHC emission for B30FFO150 fuel is lower than B30FFO100, possibly because of the higher viscosity and density, which resulted in poor atomization and led to partial combustion of fuel ascribe to higher UHC formation. Researchers have declared in their intensive researches that nanoparticles' inclusion into diesel-biodiesel fuel blend decreased the discharge of UHC emission attributable to swift and comprehensive combustion of the fuel [38-40].

\subsection{Oxides of Nitrogen (NOx)}

NOx emission in compression ignition exhaust system consists of both nitrogen dioxides (NO2) and nitric oxide (NO) gasses. Formation of NOx in internal combustion engines depends on in-cylinder peak temperature and period of this peak temperature atmosphere in combustion cycle, availability of excess $\mathrm{O} 2$ in high temperature region to react with nitrogen, and chemical structure of the fuels [41]. Figure 10 reported the distinction in NOx emission with respect to BMEP for all fuel samples. The graph indicated an escalating trend with ascend in BMEP for all fuel samples. Maximum NOx emission of $700 \mathrm{ppm}$ is obtained for PD fuel at full BMEP. With the addition of CFME to PD, escalation in NOx emission found to be $14.2 \%, 23.42 \%$, and $33.42 \%$ for B10, B20, and B30 fuels respectively with respect to $\mathrm{PD}$. This augmented behavior might be attributable to the intrinsic oxygen content in CFME blends, along with peak combustion temperature during blended fuels operations. Sivasaravanan et al. [42] operated diesel engine with neem oil biodiesel blends and claimed an escalation in NOx emission for those blends due to high in-cylinder temperature and pressure as a result of burning of more fuel in consequence of lower calorific value, higher viscosity and higher oxygen content in biodiesel blends.

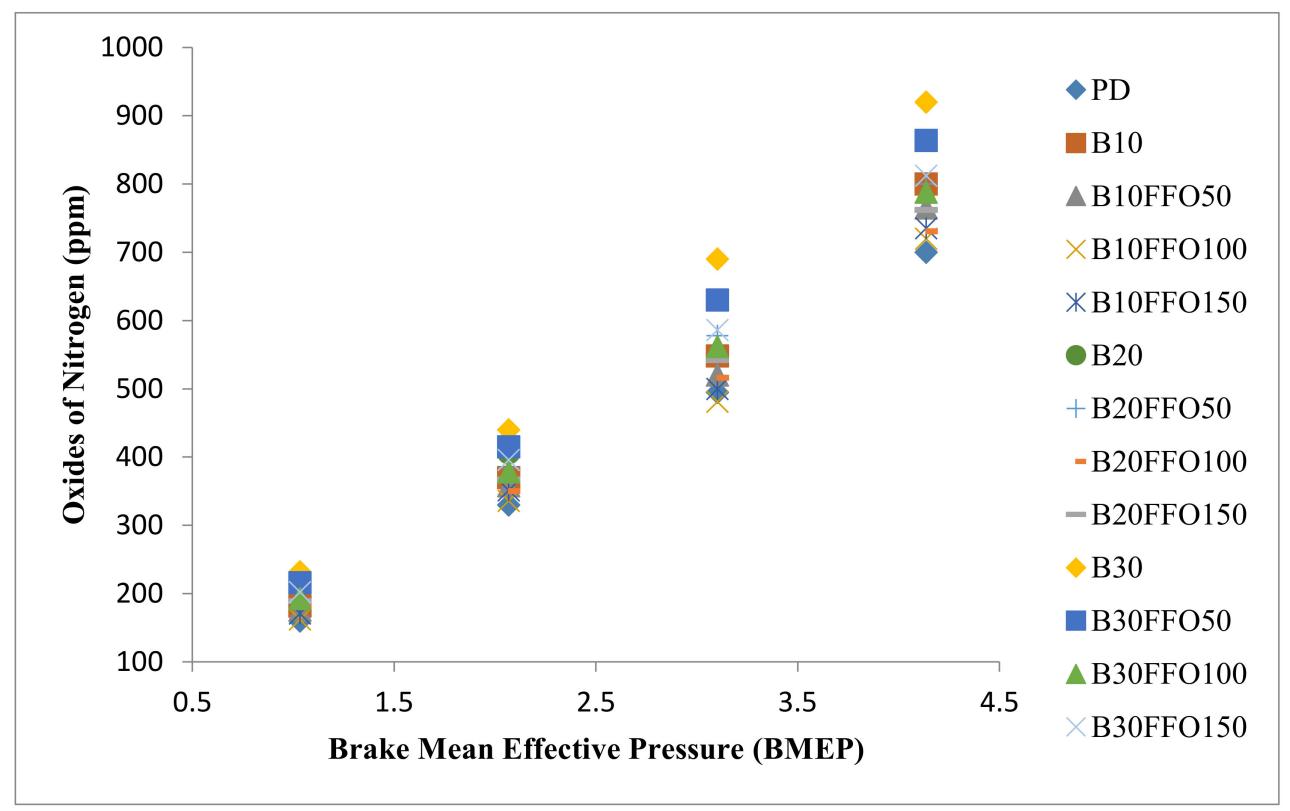

Figure 10. Comparison of NOx with BMEP. 
However, in this study, the NOx emission for CFME blends is curbed by the incorporation of tiny concentrations of FFO nanoparticles to them. Because of the exceptional properties of FFO nanoparticles, such as superior thermal conductivity, heat transfer characteristics and spray characteristics, quality of combustion can become better. With the healthier mass and heat conveyed during combustion, fuel particle burns uniformly throughout the combustion, resulting in a reduction in flame spots (NOx prone zones), thus overall NOx formation is reduced [43,44]. In addition, the presence of employed nanoparticles in biodiesel blends could respond as NOx reduces during combustion, which can smash the structure of NOx into nitrogen and oxygen, thus lowering the NOx generation [19]. The NOx emissions for the tested fuels are obtained in the following order: $\mathrm{PD}<$ nano-additive fuels $(50 \mathrm{ppm}>150 \mathrm{ppm}>100 \mathrm{ppm})<$ CFME blends $(\mathrm{B} 10<\mathrm{B} 20<\mathrm{B} 30)$. $100 \mathrm{ppm}$ provided the sympathetic results of NOx emission among all concentrations, therefore comparisons of $100 \mathrm{ppm}$ nano-additive fuels with non-nano-additive fuels are becoming present. The above results clearly proved that NOx emission reduces up to 100 ppm dosage of FFO nanoparticles. It increased for 150 ppm dosage of FFO nanoparticles because nanoparticles started to agglomerate at this dose and tends to reduce catalytic effect of particles which resulted in the formation of flame spots in combustion chamber thus produce higher NOx. Descent in NOx emission is found to be $10 \%$ for B10FFO100, $15.39 \%$ for $\mathrm{B} 20 \mathrm{FFO} 100$, and $14.34 \%$ for $\mathrm{B} 30 \mathrm{FFO} 100$ with respect to $\mathrm{B} 10, \mathrm{~B} 20$, and $\mathrm{B} 30$ blends respectively, whereas when compared these nano-additive fuels result with the PD result, a slight ascension of $2.8 \%, 4.42 \%$, and $12.57 \%$, noted in NOx emission. The incorporation of FFO nanoparticles into diesel fuel can reduce the NOx emission, but to know the output variation, an investigation needs to be carried out. Similar observations for nano-additive fuels were reported by Manigandan et al. [45] and Radhakrishnan et al. [46].

\subsection{Smoke Emission}

Smoke is an aerosol of particles and droplets, which comprises almost 8 carbon and 1-hydrogen parts [47]. The newly formed soot particles consist of maximum hydrogen molecules, in which $\mathrm{H} / \mathrm{C}$ ratio is greater than one, however, as the soot particles initiate to mature, lowering the hydrogen fraction. Srivastava et al. [48] reported that soot density to be $1.84 \pm 0.1 \mathrm{~g} / \mathrm{cm}^{3}$. The oxidation of soot is increased when high reaction temperature, sufficient reaction time, and plenty oxygen in reaction are existing. The smoke particles are mainly oxidized at the surface of flame, which relies on the turbulence level, and most of the injected fuel will pass off vaporization at the time of ignition delay period which form soot particles. The unblemished combustion of fuel is presumable when there is an adequate residence time available (reduction in ignition delay) for the oxidation [47].

The effect of smoke emission against BMEP for all tested samples is indicated in Figure 11. For all fuels, the smoke emission ascends with BMEP, due to augmentation in consumption, which leads to a rich mixture. The graph clearly indicated that smoke emission for all CFME blends is inferior to PD due to intrinsic oxygen present in CFME structure, because of which the mean size of fuel spray droplet remains small which causes boost $\mathrm{A} / \mathrm{F}$ mixing process, resulting in lean fuel zone inside combustion chamber (increase soot oxidation), thus lesser smoke formation [49]. At maximum BMEP, 1.51\%, 5.39\%, and $11.65 \%$ smoke reductions are found for B10, B20, and B30 blends respectively compared to PD. Results clearly exhibited that B30 blend demonstrated the optimum result among non-additive fuels.

Smoke emission further decrease with FFO nano-particles doped CFME blends. At full BMEP, decrease in smoke for B30FFO50, B30FFO100, and B30FFOM150 blends found to be $4.26 \%, 15.64 \%$, and $11.76 \%$ respectively collated to the B30 blend. Among all nanoparticles dosage, $100 \mathrm{ppm}$ dosage demonstrated the optimum smoke reduction in all nano-additive fuels. The $150 \mathrm{ppm}$ nanoparticles proportions gave lesser drop in smoke emission compared to $100 \mathrm{ppm}$, possibly because of an increase in the agglomeration of particles, which leads to lessening in the effective surface area of particles. However, decrease in smoke with all nano-additive blends is mainly due to the existence of oxygen molecules in the functional 
group of FFO nanoparticles which released to the combustion zone during the premixed combustion phase. The abruptly availability of oxygen enhanced the burning rate of fuel which leads to reduced ignition delay, resulting in more fuel burnt during diffusion stage and increase the oxidation of soot particles, hence lower smoke formation [34]. Similar observations for three different nano-additives are noticed by Gad and Jayaraj [17].

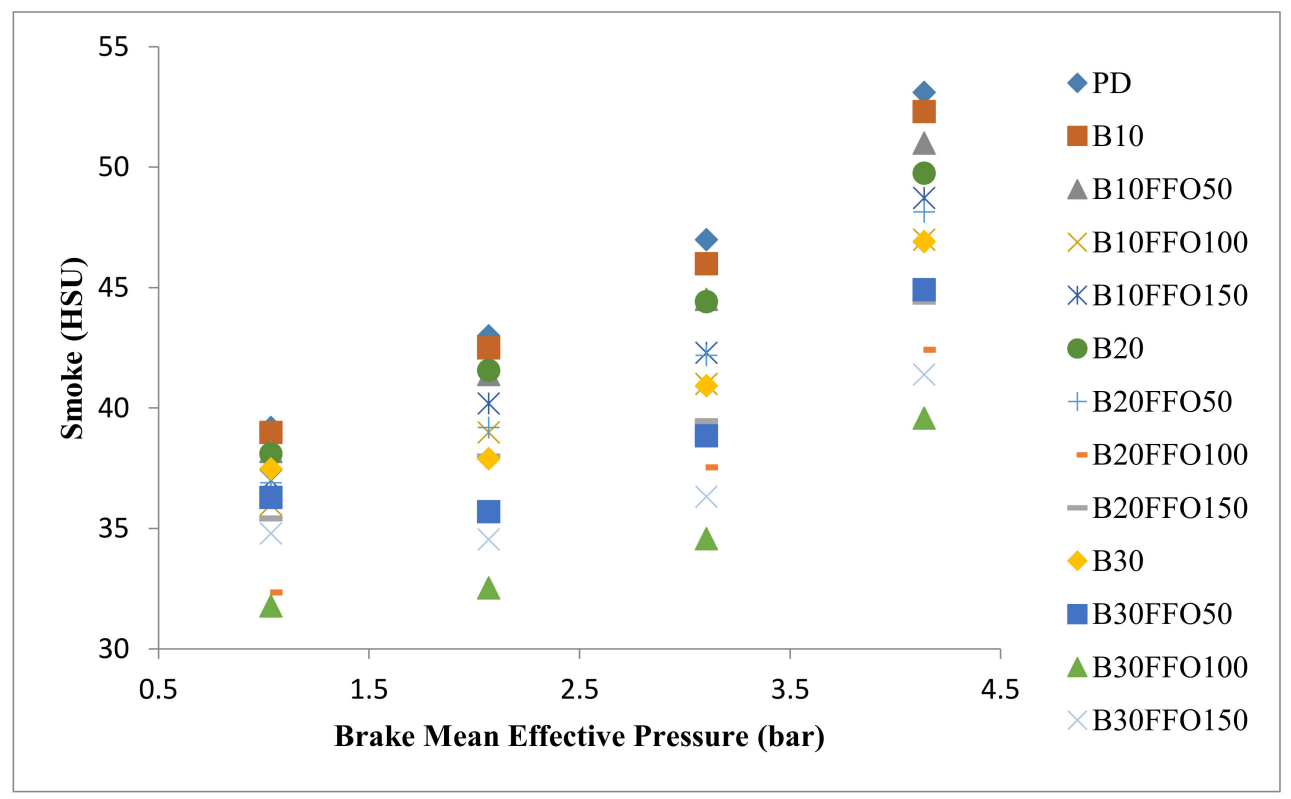

Figure 11. Comparison of smoke with BMEP.

\subsection{Brake Thermal Efficiency (BTE)}

BTE is a superlative benchmark of engine performance which reflects the combustionability of fuels. In general, BTE indicates how efficiently the chemical energy of fuel is converted into useful work output. Figure 12 illustrates how to vary BTE to rely on the fuel nature and engine BMEP. For all tested samples, BTE tends to increase with elevate in BMEP credited to the combined effect of higher brake power and lower heat rejection rate for corresponding increase in fuel rate [19,50]. At full BMEP, insignificant descend in BTE found to be $3.55 \%$ for B10, 7.09\% for B20, and $9.75 \%$ for B30 in contrast to PD fuel. This fall in BTE for CFME blends occurred, caused by higher mass flow rate of fuel, higher viscosity and lower calorific value of CFME [51].

Momentous improvement in BTE observed with CFME blends when nanoparticles added in those blends. By addition of $50 \mathrm{ppm}, 100 \mathrm{ppm}$, and $150 \mathrm{ppm}$ nanoparticles to B10, improvement of $1.05 \%, 2.13 \%$, and $1.8 \%$ are observed. Similarly, when particles added in B20, $2.97 \%, 4.84 \%$, and $3.65 \%$ increments in BTE are attained, and addition of these three concentrations of particles to B30 improved the BTE by $2.71 \%, 6.15 \%$, and $5.3 \%$. The reason behind this improvement is the augmentation in burning process on account of high surface-volume ratio, catalytic activity of FFO nanoparticles, and micro-explosion of fuel droplets that leads to healthier A/F mixing and rapid evaporation resulting in superior fuel oxidation thus higher BTE [52]. FFO additive improves the calorific value of test fuels and minimizes the ignition delay time and both these factors also help in improving BTE. It is also seen that by increasing nanoparticles' concentration from $50 \mathrm{ppm}$ to $100 \mathrm{ppm}$, BTE improves and the same trend was observed by Vali and Wani [53] because of quicker heat liberation during the burning process. 


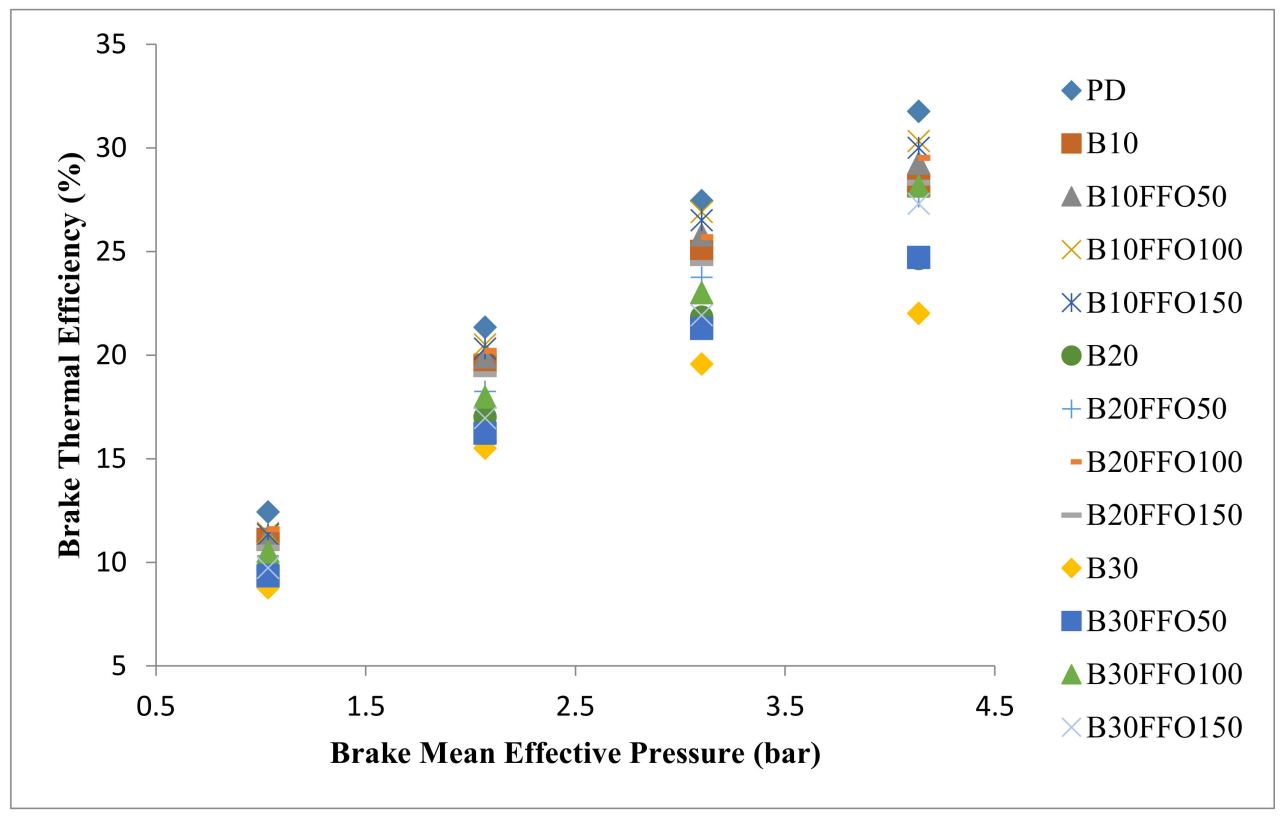

Figure 12. Comparison of Brake thermal efficiency (BTE) with BMEP.

\subsection{Brake Specific Fuel Consumption (BSFC)}

Amount of fuel consumed by an engine to generate unit brake power output is referred to as BSFC, which reflects the combustion efficiency of test fuels. Figure 13 displayed how to vary BSFC for test fuels at different BMEP. It can be seen from the figure that increasing the concentration of CFME in blends ascend the BSFC attributed to the lower calorific value of CFME, as a result of injection of additional fuel to reach the same power output. Therefore, BSFC displays the opposite fashions according to BTE fashions [54]. Hence, the result of BSFC for non-additive blends is predictable in the following manner: $\mathrm{PD}$ $(292.55 \mathrm{~g} / \mathrm{kW} \cdot \mathrm{h})<\mathrm{B} 10(318 \mathrm{~g} / \mathrm{kW} \cdot \mathrm{h})<$ B20 $(345.08 \mathrm{~g} / \mathrm{kW} \cdot \mathrm{h})<\mathrm{B} 30(360 \mathrm{~g} / \mathrm{kW} \cdot \mathrm{h})$.

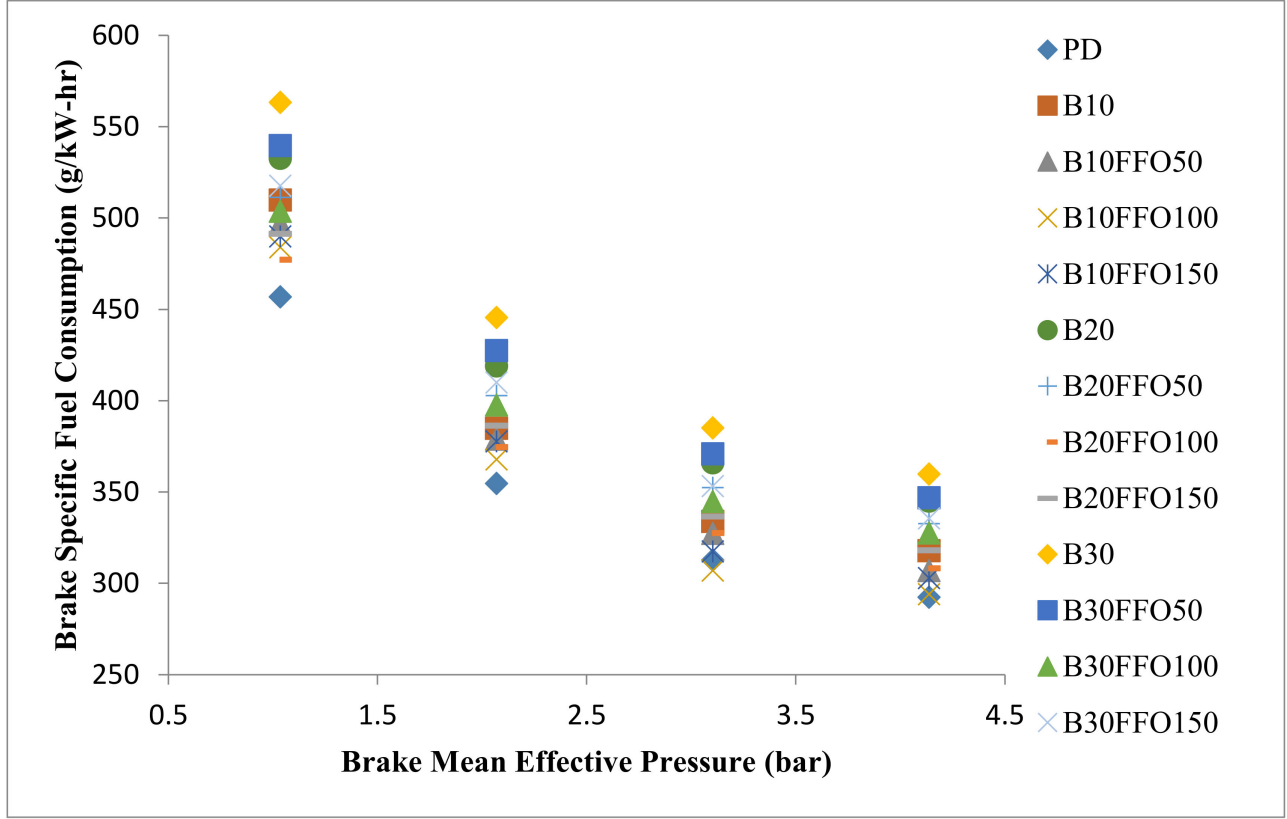

Figure 13. Comparison of brake specific fuel consumption (BSFC) with BTE.

It is examined that there is a pivotal drop in BSFC with FFO-blended CFME blends at all BMEP. It is attributed that nanoparticle incorporation develops the fuel heating value 
and actuates the fine atomization of the test fuel droplets because of the micro-explosion phenomenon, which leads to a reduced ignition delay. Due to shorter ignition delay, more fuel is combust in pre-mixed combustion stage at the early-on phase of expansion stroke, as a result of more power being generated that decreases the BSFC [53,55]. Another reason for BSFC drop could be the improved fuel quality (i.e., augmented in oxygen molecules). For all blends, maximum reduction in BSFC is seen at apex BMEP when $100 \mathrm{ppm}$ particles are diluted in those blends. For B10FFO100, B20FFO100, and B30FFO150 nano-additive blends, maximum reductions of $8.10 \%, 10.64 \%$, and $8.97 \%$ are observed as compared to non-additive blends correspondingly.

\subsection{Brake Specific Energy Consumption (BSEC)}

When the engine was operated with diverse calorific value fuels, in that case, comparison of BSEC could possibly be a more vital parameter than BSFC, since it provides more precise results. Figure 14 demonstrates the comparison profile of BSEC for all tested fuel samples. It is noted from the graph that BSEC of B30 (15.02 MJ/kw.h) blend is highest followed by B20 $(14.66 \mathrm{MJ} / \mathrm{kw} \cdot \mathrm{h})$ and B10 $(13.59 \mathrm{MJ} / \mathrm{kw} \cdot \mathrm{h})$ blends. Increasing the concentration of CFME in blend decreases the calorific value and increases the viscosity of blend and these adverse fluctuations in blend properties impoverishes the droplet's atomization resulting in lower vaporization rate, which is accountable for increment in BSEC [56].

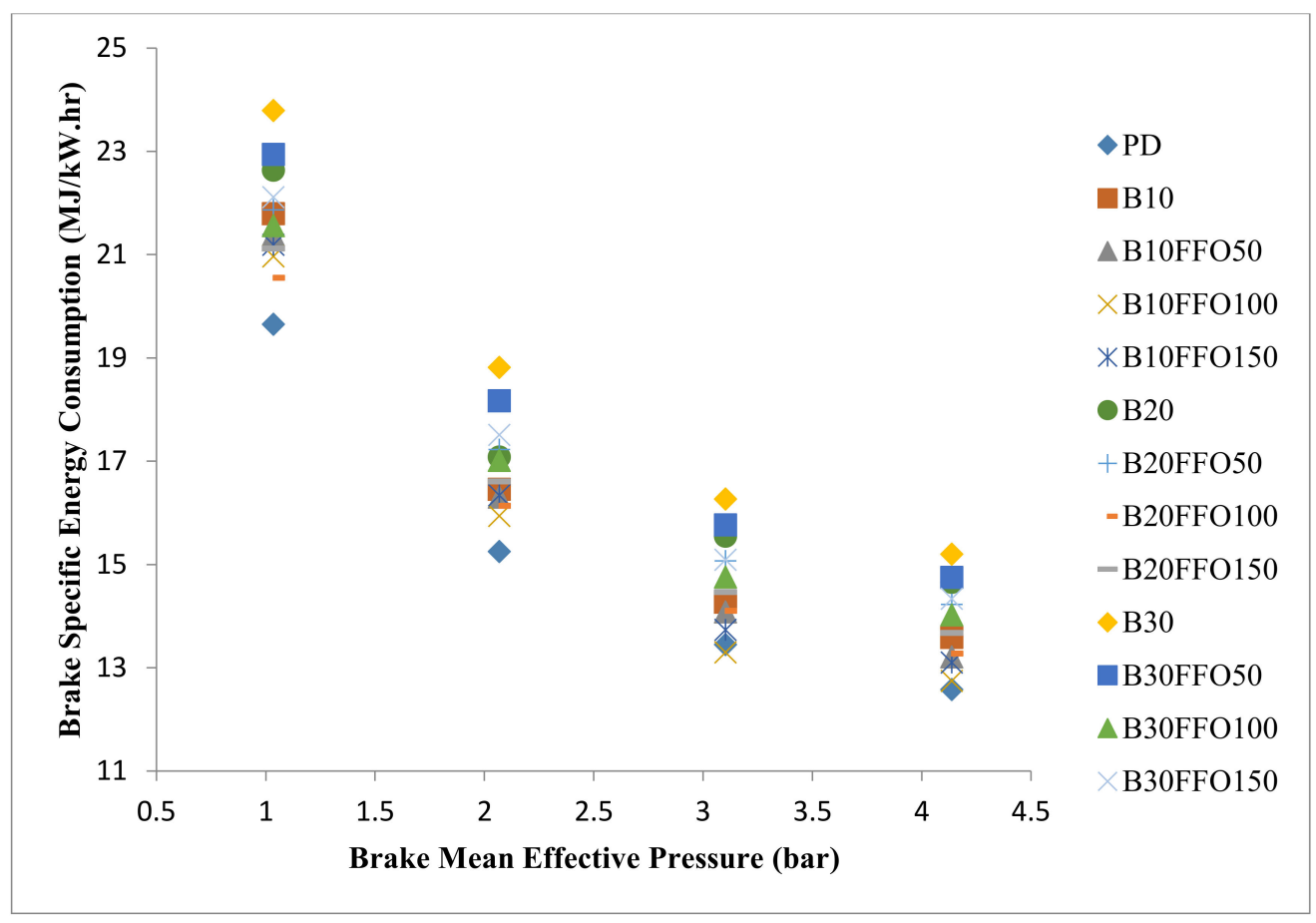

Figure 14. Comparison of BSEC with BMEP.

It has been noted that fuel-borne nano-additive incorporated fuels decrease the BSEC. Reduction of $6.22 \%, 9.44 \%$ and $7.74 \%$ are noted for B10FFO100, B20FFO100, and B30FFOM100 blends, in comparison to B10, B20 and B30 blends, respectively. The delivery of additional oxygen molecules by nano-additives during combustion reaction, and augmentation in heat transfer and momentum exchange (due to high catalytic effect) in between burned and unburned fuel molecules within the combustion chamber are two prominent reasons which are accountable for better fuel vaporization, and therefore lower BSEC attained for nano-additive fuels [19]. Reduced physical ignition delay and better cetane number also debit to lower BSEC. Among all nano-additive dosage, $100 \mathrm{ppm}$ dosage exhibits the lower BSEC with all CFME blends, which could possibly result of the liberation of a significant amount of energy during $100 \mathrm{ppm}$ additive fuels combustion. Moreover, 
the incorporation of nano-additives results in lowered ignition delay, higher evaporation rate, and superior spray penetration, which altogether develops the catalytic activity and enhanced combustion efficiency, thereby resulting in a lower BSEC level for nano-additive fuels. Similar observation for BSEC was observed by Venue et al. [56], Patel and Kumar [57], and Prabu and Anand [58].

\subsection{Exhaust Gas Temperature (EGT)}

In most cases, EGT gives a signal of the conversion rate of fuel into heat in the experimental engine. In general, high EGT is not anticipated because it indicates low heat utilization as a result of low thermal efficiency [59]. The effect of EGT at different BMEP for all test fuel is plotted in Figure 15. The graph clearly shows that the blending of CFME into PD enhances the EGT attributed to lower heating value and the viscous nature of CFME led to extenuate fuel burning process, which means that more fuel burns in the burning phase and after the burning phase as well, thus higher EGT [60]. In comparison of PD, EGT for $\mathrm{B} 10, \mathrm{~B} 20$ and B30 is higher by $8.5 \%, 21.99 \%$, and $32.55 \%$, respectively. The dispersion of FFO nanoparticles into CFME blends declines the EGT attributed to decreased ignition delay and efficient combustion, as a result of which maximum heat got released itself within the combustion chamber caused by EGT got declined. The addition of $100 \mathrm{ppm}$ nanoparticles in comparison of $50 \mathrm{ppm}$ and $150 \mathrm{ppm}$ concentration of nanoparticles offered the better outcome of EGT minimization attributed to superior catalytic effect for this concentration, resulting in efficient combustion. Lessening in EGT for B10FFO100, B20FFO100, and B30FFO100 nano-fuels was found to be $14.05 \%, 19.47 \%$, and $24.5 \%$ with respect to B10, B20 and B30 non-additive blends correspondingly. Similar results were also recorded in earlier investigations of Khan et al. [35] and Purushothaman et al. [61].

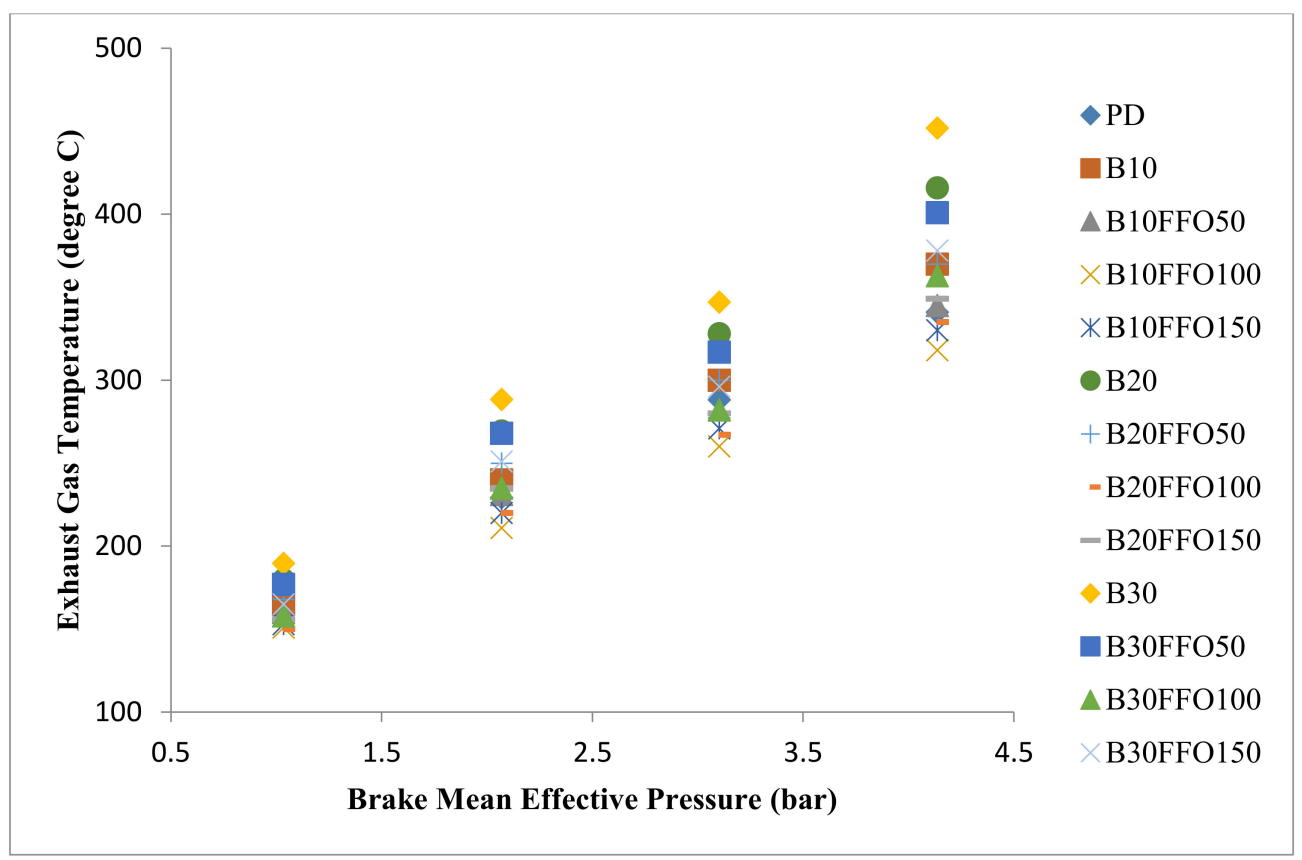

Figure 15. Comparison of exhaust gas temperature (EGT) with BMEP.

\section{Conclusions}

An experimental study with regard to performance and emission parameters is carried out for a single cylinder DICI engine using PD, CFME blends and nano-additives fuels. Ferrous ferric oxide (FFO) nanoparticles are dispersed (50, 100, and $150 \mathrm{ppm}$ ) in blend and applied the ultrasound technique to prepare the stable nano-additive fuels. Based on the outcomes obtained from experiments, the following conclusions are derived: 
- Engine operated with non-nano-additive blends produces significantly lower emissions of $\mathrm{CO}$, UHC and smoke, whereas NOx emission found to be increase with increasing CFME concentration in blend. In addition, BTE is lower with CFME blend, due to lower calorific value of CFME unquestionably thereby higher BSFC and higher BSEC got attain for those blends.

- The dilution of nanoparticles in CFME blends further reduces the CO, UHC, and smoke emission. Besides, NOx emission also found to be reducing for nano-additive fuels. In addition, BTE was noted to be increased, while BSFC and BSEC observed to be decrease for those nano-additive blends in comparison to neat tested blends.

- Among all three concentrations of FFO nanoparticles, 100 ppm concentration offered the optimum result of performance (BTE, BSFC, BSEC, and EGT) and emission (CO, UHC, NOx, and smoke) characteristics with all CFME blends.

- The incorporation of $100 \mathrm{ppm}$ dosage into CFME blends enhanced the vaporization process, which led to lower physical ignition resulting in efficient combustion (higher efficiency and lower emissions).

- Beyond 100 ppm concentration, engine performance starts to decrease and deleterious emissions also start to elevate due to decrease in activated catalytic surface, which is the result of particles agglomeration.

- Maximum decrements in CO by $56.66 \%$, UHC by $22.72 \%$ and smoke by $15.64 \%$ noted for B30FFO100 nano-fuel in comparison with B30 blend. However, engine efficiency is higher by $6.15 \%$ than B30; nevertheless, it is lower by $3.6 \%$ than PD.

- Maximum reductions in BSFC by $10.64 \%$, BSEC by $9.44 \%$ and EGT by $19.47 \%$ are noticed for B20FFO100 in comparison of B20 blend. Besides, maximum reduction in NOx emission by $15.39 \%$ is also observed for this nano-fuel blend. BTE is improved by $4.84 \%$ for B20FFO100 compared to B20. However, increment in BTE for B20FFO100 fuel is lower than B30FFO100 fuel; nevertheless, it is quite close to the PD.

- From analysis of all experimental results, it can be concluded that B20FFO100 among all nano-additive fuels provides the maximum performance results and optimum emission outputs in the diesel engine.

- Higher dosage of FFO nanoparticles in fuel starts to agglomerate that reduces surface to area volume ratio as a result in decreasing the catalytic activity of nanoparticles. Besides, a higher dosage of nanoparticles also increases the viscosity and density of fuel, resulting in deprived atomization. Therefore, the performance of high dosage doped nano-additive fuel was reduced.

- The utilization of FFO nanoparticles with pure diesel fuel can reduce the emissions (CO, UHC, NOx, and smoke), and significantly improve the performance of $\mathrm{CI}$ engine. Nonetheless, an investigation needs to be done to obtain the validated information.

The engine was operated for four months and the authors did not observe any adverse effects on efficiently functioning of engine with the addition of ferrous ferric oxide (FFO) nanoparticles. Besides, no carbon deposits were observed in the carburetor and fuel tank. However, enduring investigations on the lifecycle of the engine and engine's components are needed to conduct. The results reveal that FFO nanoparticles are appropriate nanoadditives in CFME blend for improving the performance and emission characteristics of a compression ignition engine.

Author Contributions: A.S.: Conceptualization, Methodology, Investigation, and Writing-original draft; N.A.R.: Supervision, Project administration, Review \& Editing; M.R.A.R.: Supervision, Validation of results, and Interpretation of data; K.A.B.A.: Supervision, Formal analysis, Review \& Editing; Y.H.T.: Design, Analysis, Review \& Editing; N.Z.A.: Formal analysis and Reviewing. All authors have read and agreed to the published version of the manuscript.

Funding: The authors would like to acknowledge the financial support provided by Universiti Pertahanan Nasional Malaysia (UPNM), Malaysia under the Short Term Grant (J0234-UPNM/2020/GPJP/ TK/10) and Universiti Sains Malaysia (USM), Malaysia under the Fundamental Research Grant 
Scheme (FRGS)-203.PMEKANIK.6071444 (Title: Mechanism Study of Combustion and Formulation of Surrogate Biomass Producer Gas Using a CVCC System).

Institutional Review Board Statement: Not applicable.

Informed Consent Statement: Not applicable.

Data Availability Statement: The data related to this study are available in this paper.

Conflicts of Interest: The authors declare no conflict of interest.

$\begin{array}{ll}\text { Abbreviations } \\ \text { CFME } & \text { Chicken fat methyl ester } / \text { biodiesel } \\ \text { FFO } & \text { Ferrous ferric oxide } \\ \text { PD } & \text { Pure diesel } \\ \text { KOH } & \text { Potassium hydroxide } \\ \text { ppm } & \text { Parts per million } \\ \text { B10 } & 10 \% \text { biodiesel }+90 \% \text { pure diesel } \\ \text { B10FFO50 } & 10 \% \text { biodiesel }+90 \% \text { pure diesel }+50 \text { ppm FFO } \\ \text { B10FFO100 } & 10 \% \text { biodiesel }+90 \% \text { pure diesel }+100 \text { ppm FFO } \\ \text { B10FFO150 } & 10 \% \text { biodiesel }+90 \% \text { pure diesel }+150 \text { ppm FFO } \\ \text { B20 } & 20 \% \text { biodiesel }+80 \% \text { pure diesel } \\ \text { B20FFO50 } & 20 \% \text { biodiesel }+80 \% \text { pure diesel }+50 \text { ppm FFO } \\ \text { B20FFO100 } & 20 \% \text { biodiesel }+80 \% \text { pure diesel }+100 \text { ppm FFO } \\ \text { B20FFO150 } & 20 \% \text { biodiesel }+80 \% \text { pure diesel }+150 \text { ppm FFO } \\ \text { B30 } & 30 \% \text { biodiesel }+70 \% \text { pure diesel } \\ \text { B30FFO50 } & 30 \% \text { biodiesel }+70 \% \text { pure diesel }+50 \text { ppm FFO } \\ \text { B30FFO100 } & 30 \% \text { biodiesel }+70 \% \text { pure diesel }+100 \text { ppm FFO } \\ \text { B30FFO150 } & 30 \% \text { biodiesel }+70 \% \text { pure diesel }+150 \text { ppm FFO } \\ \text { BMEP } & \text { Brake mean effective pressure } \\ \text { A/F } & \text { Air fuel ratio } \\ \text { CO } & \text { Carbon monoxide } \\ \text { UHC } & \text { Unburned hydrocarbon } \\ \text { NOx } & \text { Oxides of nitrogen } \\ \text { BTE } & \text { Brake thermal efficiency } \\ \text { BSFC } & \text { Brake specific fuel consumption } \\ \text { BSEC } & \text { Brake specific energy consumption } \\ \text { EGT } & \text { Exhaust gas temperature } \\ \text { CA } & \text { Crank angle } \\ \text { HSU } & \text { Hartridge smoke unit } \\ & \end{array}$

\section{References}

1. Conti, J.; Holtberg, P.; Diefenderfer, J.; LaRose, A.; Turnure, J.T.; Westfall, L. International Energy Outlook 2016; U.S. Energy Information Administration: Washington, DC, USA, 2016; Volume 0484, ISBN 2025866135.

2. Yuvarajan, D.; Babu, M.D.; Beemkumar, N.; Kishore, P.A. Experimental investigation on the influence of titanium dioxide nanofluid on emission pattern of biodiesel in a diesel engine. Atmos. Pollut. Res. 2017, 9, 1-6. [CrossRef]

3. Manigandan, S.; Gunasekar, P.; Devipriya, J.; Nithya, S. Emission and injection characteristics of corn biodiesel blends in diesel engine. Fuel 2019, 235, 723-735. [CrossRef]

4. Atabani, A.E.; Shobana, S.; Mohammed, M.N.; Uğuz, G.; Kumar, G.; Arvindnarayan, S.; Aslam, M.; Al-muhtaseb, A.H. Integrated valorization of waste cooking oil and spent coffee grounds for biodiesel production: Blending with higher alcohols, FT-IR, TGA, DSC and NMR characterizations. Fuel 2019, 244, 419-430. [CrossRef]

5. Saxena, V.; Kumar, N.; Kumar, V. Multi-objective optimization of modified nano fl uid fuel blends at different TiO2 nanoparticle concentration in diesel engine: Experimental assessment and modeling. Appl. Energy 2019, 248, 330-353. [CrossRef]

6. Milano, J.; Ong, H.C.; Masjuki, H.H.; Silitonga, A.S.; Chen, W.; Kusumo, F.; Dharma, S.; Sebayang, A.H. Optimization of biodiesel production by microwave irradiation-assisted transesterification for waste cooking oil-Calophyllum inophyllum oil via response surface methodology. Energy Convers. Manag. 2018, 158, 400-415. [CrossRef]

7. Saravanan, A.; Murugan, M.; Reddy, M.S.; Parida, S. Performance and emission characteristics of variable compression ratio CI engine fueled with dual biodiesel blends of Rapeseed and Mahua. Fuel 2020, 263, 116751. [CrossRef] 
8. Mahlia, T.M.I.; Syazmi, Z.A.H.S.; Mofijur, M.; Abas, A.E.P.; Bilad, M.R.; Ong, H.C.; Silitonga, A.S. Patent landscape review on biodiesel production: Technology updates. Renew. Sustain. Energy Rev. 2020, 118, 109526. [CrossRef]

9. Ong, H.C.; Masjuki, H.H.; Mahlia, T.M.I.; Silitonga, A.S.; Chong, W.T. Engine performance and emissions using Jatropha curcas, Ceiba pentandra and Calophyllum inophyllum biodiesel in a CI diesel engine. Energy 2014, 69, 1-19. [CrossRef]

10. Gul, M.; Masjiki, H.H.; Kalam, M.A.; Zulkifli, N.W.M.; Mujtaba, M.A. A Review: Role of Fatty Acids Composition in Characterizing Potential Feedstock for Sustainable Green Lubricants by Advance Transesterification Process and its Global as Well as Pakistani Prospective. BioEnergy Res. 2019, 13, 1-22. [CrossRef]

11. Sarvestani, N.S.; Tabasizadeh, M.; Abbaspour-fard, M.H.; Nayebzedeh, H.; Karimi-Maleh, H.; Van, T.C.; Jafari, M.; Ristovski, $\mathrm{Z}$.; Brown, R.J. Influence of doping $\mathrm{Mg}$ cation in $\mathrm{Fe}_{3} \mathrm{O}_{4}$ lattice on its oxygen storage capacity to use as a catalyst for reducing emissions of a compression ignition engine. Fuel 2020, 272, 117728. [CrossRef]

12. Ozgur, T.; Tuccar, G.; Uludamar, E.; Yilmaz, A.C.; Güngör, C.; Ozcanli, M.; Serin, H.; Kadir, A. Effect of nanoparticle additives on NOx emissions of diesel fuelled compression ignition engine. Int. J. Glob. Warm. 2015, 7, 487-498. [CrossRef]

13. Kumar, T.D.; Hussain, S.S.; Ramesha, D.K. Effect of a zinc oxide nanoparticle fuel additive on the performance and emission characteristics of a CI engine fuelled with cotton seed biodiesel blends. Mater. Today Proc. 2020, 26, 2374-2378. [CrossRef]

14. Rastogi, P.M.; Sharma, A.; Kumar, N. Effect of $\mathrm{CuO}$ nanoparticles concentration on the performance and emission characteristics of the diesel engine running on jojoba (Simmondsia Chinensis) biodiesel. Fuel 2021, 286, 119358. [CrossRef]

15. Ali, S.A.; Hunagund, S.; Hussain, S.S.; Bagwan, A.H. The effect of nanoparticles dispersed in waste cooking oil (WCO) biodiesel on thermal performance characteristics of VCR engine. Mater. Today Proc. 2020, 1-4.

16. Vigneswaran, R.; Balasubramanian, D.; Sastha, B.D.S. Performance, emission and combustion characteristics of unmodified diesel engine with titanium dioxide (TiO2) nano particle along with water-in-diesel emulsion fuel. Fuel 2021, 285, 119115. [CrossRef]

17. Gad, M.S.; Jayaraj, S. A comparative study on the effect of nano-additives on the performance and emissions of a diesel engine run on Jatropha biodiesel. Fuel 2020, 267, 117168. [CrossRef]

18. Mujtaba, M.A.; Kalam, M.A.; Masjuki, H.H.; Gul, M.; Soudagar, M.E.M.; Ong, H.C.; Ahmed, W.; Atabani, A.E.; Razzaq, L.; Yusoff, M. Comparative study of nanoparticles and alcoholic fuel additives-biodiesel- diesel blend for performance and emission improvements. Fuel 2020, 279, 118434. [CrossRef]

19. Nanthagopal, K.; Ashok, B.; Tamilarasu, A.; Johny, A.; Mohan, A. Influence on the effect of zinc oxide and titanium dioxide nanoparticles as an additive with Calophyllum inophyllum methyl ester in a CI engine. Energy Convers. Manag. 2017, 146, 8-19. [CrossRef]

20. Muthusamy, S.; Nallathambi, S.S.; Ramasamy, R.K.; Mohamed, S.T. Effects of Nanoparticles blended Biodiesel on Single Cylinder CI Engine. Mater. Today Proc. 2018, 5, 6831-6838. [CrossRef]

21. Aalam, C.S. Investigation on the combustion and emission characteristics of CRDI diesel engine fuelled with nano Al2O3 and Fe3O4 particles blended biodiesel. Mater. Today Proc. 2020, 33, 2540-2546.

22. Wu, Q.; Xie, X.; Wang, Y.; Roskilly, T. Effect of carbon coated aluminum nanoparticles as additive to biodiesel-diesel blends on performance and emission characteristics of diesel engine. Appl. Energy 2018, 221, 597-604. [CrossRef]

23. Debbarma, S.; Misra, R.D. Effects of iron nanoparticles blended biodiesel on the performance and emission characteristics of a diesel engine. J. Energy Resour. Technol. 2017, 139, 042212. [CrossRef]

24. Soudagar, M.E.M.; Nik-Ghazali, N.N.; Kalam, M.A.; Badruddin, I.A.; Banapurmath, N.R.; Bin Ali, M.A.; Kamangar, S.; Cho, H.M.; Akram, N. An investigation on the influence of aluminium oxide nano-additive and honge oil methyl ester on engine performance, combustion and emission characteristics. Renew. Energy 2020, 146, 2291-2307. [CrossRef]

25. Soudagar, M.E.M.; Nik-Ghazali, N.N.; Kalam, M.A.; Badruddin, I.A.; Banapurmath, N.R.; Yunus Khan, T.M.; Bashir, M.N.; Akram, N.; Farade, R.; Afzal, A. The effects of graphene oxide nanoparticle additive stably dispersed in dairy scum oil biodiesel-diesel fuel blend on CI engine: Performance, emission and combustion characteristics. Fuel 2019, 257, 116015. [CrossRef]

26. Kirubakaran, M.; Selvan, V.A.M. A comprehensive review of low cost biodiesel production from waste chicken fat. Renew. Sustain. Energy Rev. 2018, 82, 390-401. [CrossRef]

27. Barik, D.; Vijayaraghavan, R. Effects of waste chicken fat derived biodiesel on the performance and emission characteristics of a compression ignition engine. Int. J. Ambient Energy 2018, 1-10. [CrossRef]

28. Sarin, A. Biodiesel: Production and Properties, 2012th ed.; Royal Society of Chemistry: Cambridge, UK, $2012 ;$ ISBN 9781849734707.

29. Adewale, P.; Dumont, M.J.; Ngadi, M. Recent trends of biodiesel production from animal fat wastes and associated production techniques. Renew. Sustain. Energy Rev. 2015, 45, 574-588. [CrossRef]

30. Ma, F.; Hanna, M.A. Biodiesel production: A review. Bioresour. Technol. 1999, 70, 1-15. [CrossRef]

31. Heidari-maleni, A.; Gundoshmian, T.M.; Karimi, B.; Jahanbakhshi, A.; Ghobadian, B. A novel fuel based on biocompatible nanoparticles and ethanol-biodiesel blends to improve diesel engines performance and reduce exhaust emissions. Fuel 2020, 276, 118079. [CrossRef]

32. Khalife, E.; Tabatabaei, M.; Desmirbas, A.; Aghbashlo, M. Impacts of additives on performance and emission characteristics of diesel engines during steady state operation. Prog. Energy Combust. Sci. 2017, 59, 32-78. [CrossRef]

33. Ahmed, A.; Shah, A.N.; Azam, A.; Uddin, G.M.; Ali, M.S.; Hassan, S.; Ahmed, H.; Aslam, T. Environment-friendly novel fuel additives: Investigation of the effects of graphite nanoparticles on performance and regulated gaseous emissions of CI engine. Energy Convers. Manag. 2020, 211, 112748. [CrossRef] 
34. Chacko, N.; Jeyaseelan, T. Comparative evaluation of graphene oxide and graphene nanoplatelets as fuel additives on the combustion and emission characteristics of a diesel engine fuelled with diesel and biodiesel blend. Fuel Process. Technol. 2020, 204, 106406. [CrossRef]

35. Khan, H.; Soudagar, M.E.M.; Kumar, R.H.; Safaei, M.R.; Farooq, M.; Khidmatgar, A.; Banapurmath, N.R.; Farade, R.A.; Abbas, M.M.; Afzal, A.; et al. Effect of Nano-Graphene Oxide and n-Butanol Fuel Additives Blended with Diesel—Nigella sativa Biodiesel Fuel Emulsion on Diesel Engine Characteristics. Symmetry 2020, 12, 961. [CrossRef]

36. Alloune, R.; Balistrou, M.; Awad, S.; Loubar, K.; Tazerout, M. Performance, combustion and exhaust emissions characteristics investigation using Citrullus colocynthis L. biodiesel in DI diesel engine. J. Energy Inst. 2017, 1-11. [CrossRef]

37. Venu, H.; Appavu, P. $\mathrm{Al}_{2} \mathrm{O}_{3}$ nano additives blended Polanga biodiesel as a potential alternative fuel for existing unmodified DI diesel engine. Fuel 2020, 279, 118518. [CrossRef]

38. Vellaiyan, S. Enhancement in combustion, performance, and emission characteristics of a biodiesel-fueled diesel engine by using water emulsion and nanoadditive. Renew. Energy 2020, 145, 2108-2120. [CrossRef]

39. Heidari-maleni, A.; Gundoshmian, T.M.; Jahanbakhshi, A.; Ghobadian, B. Performance improvement and exhaust emissions reduction in diesel engine through the use of graphene quantum dot (GQD) nanoparticles and ethanol- biodiesel blends. Fuel 2020, 267, 117116. [CrossRef]

40. Soudagar, M.E.M.; Nik-Ghazali, N.-N.; Kalam, M.A.; Badruddin, I.A.; Banapurmath, N.R.; Akram, N. The effect of nano-additives in diesel-biodiesel fuel blends: A comprehensive review on stability, engine performance and emission characteristics. Energy Convers. Manag. 2018, 178, 146-177. [CrossRef]

41. Agarwal, A.K.; Gupta, J.G.; Dhar, A. Potential and challenges for large-scale application of biodiesel in automotive sector. Prog. Energy Combust. Sci. 2017, 61, 113-149. [CrossRef]

42. Sivasaravanan, S.; Devi, P.B.; Nagaraj, M.; Jeevahan, J.J.; Joseph, G.B. Influence of Rice Husk Nanoparticles on Engine Performance and Emission Characteristics of Diesel and Neem Oil Biodiesel Blends in a Single Cylinder Diesel Engine. Energy Sources Part A Recover. Util. Environ. Eff. 2019, 1-16. [CrossRef]

43. Ettefaghi, E.; Ghobadian, B.; Rashidi, A.; Najafi, G.; Khoshtaghaza, M.H.; Rashtchi, M.; Sadeghian, S. A novel bio-nano emulsion fuel based on biodegradable nanoparticles to improve diesel engines performance and reduce exhaust emissions. Renew. Energy 2018, 125, 1-26. [CrossRef]

44. Kannaiyan, K.; Sadr, R.; Kumaravel, V. Application of Nanoparticles in Clean Fuels. In Nanostructured Materials for Energy Related Applications; Springer: Cham, Switzerland, 2019; pp. 223-242; ISBN 9783030045005.

45. Manigandan, S.; Gunasekar, P.; Nithya, S.; Devipriya, J. Effects of nanoadditives on emission characteristics of engine fuelled with biodiesel. Energy Sources Part A Recover. Util. Environ. Eff. 2019, 42, 1-9. [CrossRef]

46. Radhakrishnan, S.; Munuswamy, D.B.; Devarajan, Y.; T, A.; Mahalingam, A. Effect of nanoparticle on emission and performance characteristics of a diesel engine fueled with cashew nut shell biodiesel. Energy Sources Part A Recover. Util. Environ. Eff. 2018, 40, 2485-2493. [CrossRef]

47. Soudagar, M.E.M.; Mujtaba, M.A.; Safaei, M.R.; Afzal, A.; Raju, V.D.; Ahmed, W.; Banapurmath, N.R.; Hossain, N.; Bashir, S.; Badruddin, I.A.; et al. Effect of Sr@ZnO nanoparticles and Ricinus communis biodiesel-diesel fuel blends on modified CRDI diesel engine characteristics. Energy 2020, 215, 119094. [CrossRef]

48. Srivastava, D.K.; Agarwal, A.K.; Gupta, T. Effect of Engine Load on Size and Number Distribution of Particulate Matter Emitted from a Direct Injection Compression Ignition Engine. Aerosol Air Qual. Res. 2011, 11, 915-920. [CrossRef]

49. Ashok, B.; Nanthagopal, K.; Chyuan, O.H.; Le, P.K.; Khanolkar, K.; Raje, N.; Raj, A.; Karthickeyan, V.; Tamilvanan, A. Multifunctional fuel additive as a combustion catalyst for diesel and biodiesel in CI engine characteristics. Fuel 2020, $278,118250$. [CrossRef]

50. Kivevele, T.T.; Kristóf, L.; Bereczky, Á.; Mbarawa, M.M. Engine performance, exhaust emissions and combustion characteristics of a CI engine fuelled with croton megalocarpus methyl ester with antioxidant. Fuel 2011, 90, 2782-2789. [CrossRef]

51. Xiao, H.; Guo, F.; Wang, R.; Yang, X.; Li, S.; Ruan, J. Combustion performance and emission characteristics of diesel engine fueled with iso -butanol/biodiesel blends. Fuel 2020, 268, 117387. [CrossRef]

52. Rastogi, P.M.; Kumar, N.; Sharma, A.; Vyas, D.; Gajbhiye, A. Sustainability of Aluminium Oxide Nanoparticles Blended Mahua Biodiesel to the Direct Injection Diesel Engine Performance and Emission Analysis. Pollution 2020, 6, $25-33$.

53. Vali, R.H.; Wani, M.M. Optimal utilization of $\mathrm{ZnO}$ nanoparticles blended diesel-water emulsion by varying compression ratio of a VCR diesel engine. J. Environ. Chem. Eng. 2020, 8, 103884. [CrossRef]

54. Ümit, A.; Karagöz, M.; Sarıdemir, S.; Öztürk, A. Impact of various metal-oxide based nanoparticles and biodiesel blends on the combustion, performance, emission, vibration and noise characteristics of a CI engine. Fuel 2020, 270, 117521.

55. Debbarma, S.; Misra, R.D. Effects of Iron Nanoparticle Fuel Additive on the Performance and Exhaust Emissions of a Compression Ignition Engine Fueled With Diesel and Biodiesel. J. Therm. Sci. Eng. Appl. 2018, 10, 041002. [CrossRef]

56. Venu, H.; Raju, V.D.; Lingesan, S.; Soudagar, M.E.M. Influence of Al2O3nano additives in ternary fuel (diesel-biodiesel-ethanol) blends operated in a single cylinder diesel engine: Performance, Combustion and Emission Characteristics. Energy 2020, 215, 119091. [CrossRef]

57. Patel, H.K.; Kumar, S. Experimental Analysis on Performance of Diesel Engine using mixture of Diesel and Bio-Diesel as a Working Fuel with Aluminum Oxide Nanoparticle Additive. Therm. Sci. Eng. Prog. 2017, 4, 252-258. [CrossRef] 
58. Prabu, A.; Anand, R.B. Emission control strategy by adding alumina and cerium oxide nano particle in biodiesel. J. Energy Inst. 2015, 89, 1-22. [CrossRef]

59. Chen, X.; Wang, Z.; Pan, S.; Pan, H. Improvement of engine performance and emissions by biomass oil filter in diesel engine. Fuel 2019, 235, 603-609. [CrossRef]

60. Raju, P.; Masimalai, S.K.; Ganesan, N.; Karthic, S.V. Engine's behavior on hydrogen addition of waste cooking oil fueled light duty diesel engine-A dual fuel approach. Energy 2020, 194, 116844. [CrossRef]

61. Purushothaman, P.; Masimalai, S.; Subramani, V. Effective utilization of mahua oil blended with optimum amount of Al2O3 and $\mathrm{TiO} 2$ nanoparticles for better performance in CI engine. Environ. Sci. Pollut. Res. 2020. [CrossRef] 